\title{
Oncogenic c-Myc induces replication stress by increasing cohesins chromatin occupancy
}

\author{
Silvia Peripolli ${ }^{1}$, Tanya Singh ${ }^{1}$, Harshil Patel $^{2}$, Leticia Meneguello ${ }^{1}$, Koshiro Kiso $^{1}$, Peter Thorpe ${ }^{3}$, Cosetta Bertoli $^{1, *, \otimes}$, and \\ Robertus A.M. de Bruin ${ }^{1,4, *, \otimes}$ \\ ${ }^{1}$ MRC Laboratory for Molecular Cell Biology, University College London, Gower Street, London, WC1E 6BT, United Kingdom \\ ${ }^{2}$ Francis Crick Institute, Midland Rd 1, NW1 1AT, London, United Kingdom \\ ${ }^{3}$ Queen Mary University, Mile End Road, E1 4NS, London, United Kingdom \\ ${ }^{4}$ UCL Cancer Institute, University College London, Gower Street, WC1E 6BT, London, United Kingdom \\ equal contribution
}

\begin{abstract}
Oncogene-induced replication stress is a major driver of genomic instability in cancer cells, with a central role in both cancer initiation and progression (1). Despite its critical role in cancer development, the mechanisms that lay at the basis of oncogene-induced replication stress remains poorly understood. Here, we investigate the mechanism of c-Myc-induced replication stress. Our data shows that c-Myc induces replication stress by increasing the amount of cohesins bound to chromatin in the G1 phase of the cell cycle. This is independent of previously suggested mechanisms involving deregulation of replication initiation and transcriptional interference. Restoring the amount of chromatin-bound cohesins to control levels, or preventing the accumulation of cohesins at CTCF sites, in cells experiencing oncogenic c-Myc activity prevents replication stress. Increased cohesins chromatin occupancy correlates with a c-Mycdependent increase in the levels of the cohesion loader Mau2. Preventing c-Myc-induced increase in Mau2 reduces oncogeneinduced replication stress. Together our data support a novel mechanism for oncogene-induced replication stress. Since cMyc activation is a crucial event in many human cancers (2), identifying the mechanisms through which this oncogene promotes replication stress provides critical insights into cancer biology.
\end{abstract}

Replication stress | cohesin | c-Myc

Correspondence: r.debruin@ucl.ac.ukc.bertoli@ucl.ac.uk

Replication stress (RS) is defined as the slowing-down and/or stalling of DNA replication forks and is a major source of genomic instability in cancer cells, being often caused by activation of oncogenes or loss of tumour suppressors (3), $(1,4,5)$. Despite the critical role of oncogene-induced RS in cancer, the mechanisms that generate it remain unclear (Figure 1a). Different oncogenes have been studied in various systems, and the general consensus is that RS is likely the result of deregulation of replication initiation events (6). Other proposed mechanisms involve the interference between the replication and transcription machineries (7-9). In the case of oncogenic overexpression of Cyclin E, different mechanisms have been reported $(7,10,11)$. The reduced length of G1 following Cyclin E overexpression has been associated with a decrease in licensing events, which results in fewer replication complexes available for replication. This is thought to culminate in genomic instability due to under-replication (12). More recently, Cyclin E overexpression has also been shown to cause RS by increased transcription-replication collisions in transcribed genes $(7,11)$. In contrast, the onco- genic activity of the transcription factor c-Myc has been reported to increase replication initiation events, thus causing over-replication $(4,5)$. Surprisingly, while c-Myc is thought to induce a large transcriptional program to promote proliferation and growth (13), it has not been linked to increased transcription-replication interference.

Besides transcription machineries other large protein complexes bound to DNA could interfere with replisome progression. The cohesin complex is probably one of the most abundant protein complexes interacting with the DNA. Cohesins are ring-shaped multiprotein complexes comprising two major subunits, Structural Maintenance of Chromosome (Smc) 1 and Smc3, along with the kleisin subunit Rad21 and Stag1 and Stag2 in mammalian cells (14). The loading of cohesins onto DNA is highly regulated, and in mammalian cells depends on the activity of the loaders Mau2 and Nipped-B-like protein (NIPBL). The activity of the loaders is antagonised by the release factor Wapl (15). While loading and release occur throughout the entire cell cycle, during S-phase and G2 cohesins interaction with the DNA is more stable (16). This is due to the establishment factors, Esco1 and Esco2 in mammalian cells, which acetylate the Smc3 subunit of the cohesin complex (17), and thus prevent the release activity of Wapl (18).

Recent evidence confirmed that in mammalian cells, as previously reported in budding yeast (19), cohesin rings are able to move along the DNA in a transcription-dependent manner (20). Binding of the CCCTC-Binding Factor (CTCF) to CTCF sites is involved in the organisation of spatially interacting regions of chromatin (21), known as topologically associated domains (TADs) $(21,22)$. It has been shown that CTCF sites can act as a road-block for cohesins, with accumulation of cohesins often detected at CTCF sites in mammalian cells $(23,24)$. While the majority of cohesins interact dynamically with the DNA, some are associated more stably, and reside at CTCF sites, where they participate in the organization of chromatin loops (25).

To establish which of the different mechanisms contribute to c-Myc-induced RS, we exploited a c-Myc-ER inducible RPE1 hTERT cell line (26). In this system oncogenic c-Myc activation depends on the translocation of the c-Myc-ER protein into the nucleus after $4 \mathrm{OH}$ tamoxifen $(4 \mathrm{OH}-\mathrm{T})$ addition (Figure S1a, S1b), which is independent of c-Myc-ER protein levels (Figure S1c). $24 \mathrm{hr}$ to $48 \mathrm{hr}$ after $4 \mathrm{OH}-\mathrm{T}$ addi- 
tion oncogenic c-Myc activity can be observed via a decrease in colony formation (S1d) and increased gene expression of well-known c-Myc target genes at the mRNA (Figure S1e, S1f) and protein level (Figure S1g). As shown previously (26), activation of c-Myc-ER by $4 \mathrm{OH}-\mathrm{T}$ induces RS-induced DNA damage response within 24 hours (Figure S1i, S1j) and shortening of DNA fibre length (Figure S1k, S11), indicative of slowing down or replication forks, supporting the use of this system to study c-Myc-induced RS.

To gain some initial insights into how c-Myc induces RS, we arrested cells in different cell cycle phases, released them with or without c-Myc activation and tested the levels of RS and DNA damage in the following S phase. First, we used confluency to arrest cells in G0/G1. After release into the cell cycle, the oncogene c-Myc was activated by adding $4 \mathrm{OH}-$ $\mathrm{T}$ or left untreated as control (Figure 1b, S1m), allowing us to study the first G1 and S phases after the oncogene activation. In order to measure RS, we analysed the length of DNA fibres. The activation of c-Myc reduces the average DNA fibre length compared to control, suggestive of slowing down of replication forks (Figure 1c, 1d and Figure S1n). We then measured DNA damage by monitoring the phosphorylation of the histone H2AX. We observed increased levels of the DNA damage marker $\gamma \mathrm{H} 2 \mathrm{AX}$ in $\mathrm{S}$ phase cells with both Western blot and immunofluorescence (Figure 1e-h). We confirmed these findings by synchronising the cells via nocodazole shake-off (Figure S1o-s). These data suggest that the activation of c-Myc during $\mathrm{G} 1$ and $\mathrm{S}$ phase can induce RS and DNA damage.

To test if G1 phase is required for c-Myc to induce RS, we synchronised cells in early $\mathrm{S}$ phase by adding hydroxyurea (HU). Subsequently we washed out HU to allow S phase progression with or without c-Myc activation and analysed the levels of RS and DNA damage (Figure S2a, S2b). Surprisingly, we did not observe any decrease in DNA fibre length in c-Myc activated cells compared to control (Figure S2c). On the contrary DNA fibres appear longer upon c-Myc induction, indicating that c-Myc activity during $\mathrm{S}$ phase does not cause RS, but might even increase the replication capacity of the cell as reported in Pennycook et al (27). Correspondingly, we did not observe any increase in DNA damage in c-Myc cells (Figure S2d). As expected, c-Myc activation increased replication initiation events (origin firing, Figure S2c) and increased Cyclin E levels, a transcriptional target of c-Myc, as well as Mau2 levels (Figure S2e, S2f). This data suggests that c-Myc-induced increase in origin firing does not cause RS per se. Since HU treatment by itself causes RS, which might mask c-Myc-induced RS, we also released cells synchronously into S phase after a G1 arrest via CDK4/6 inhibition by Palbociclib, as reported by Trotter et al (28). c-Myc was activated, via addition of 4OH-T, either immediately after release, therefore throughout G1 phase, or immediately before entering S phase, and DNA damage and DNA fibre length were analysed as above (Figure S2g-j). These data confirm that c-Myc activity during $\mathrm{G} 1$ is required to generate $\mathrm{RS}$ in $\mathrm{S}$ phase.

A possible cause could be a decrease in G1 length, which has been associated with reduced origin licensing and consequent RS upon Cyclin E overexpression (12). We evaluated replication origin licensing in pre-extracted samples by measuring chromatin bound $\mathrm{Mcm} 7$, a component of the helicase complex that is loaded on the DNA during G1 as in Ekholm-Reed et al (12). We did not observe a decrease in origin licensing, (Figure S2k), indicating that reduced origin licensing is an unlikely causative mechanism for c-Myc-induced RS.

It has previously been reported that RS can result from increased transcription-replication collisions $(7,29)$. To test if interference between replication and c-Myc-induced transcription contributes to RS we decreased global transcription levels after c-Myc activation via treatment with the RNA polymerase inhibitor 5,6-Dichloro-1- $\beta$-d-Ribofuranosyl Benzimidazole (DRB) for $2 \mathrm{hr}$, , like in Kotsantis et al (8), during the first $\mathrm{S}$ phase after release from G1 (Figure S21-m). We confirmed that c-Myc activation increases global transcription levels, by 5 -Ethynyl Uridine (EU) incorporation, and that DRB reduces it, (Figure S21). However, DNA fibre analysis shows that this does not rescue the c-Myc-dependent decrease in DNA fibre length (Figure S2m). This suggests that in this system transcription-replication interference does not significantly contributes to c-Myc-induced RS levels, though we cannot exclude a role for this mechanism in other settings.

We next focused on alternative mechanisms that could contribute to c-Myc-induced RS. A potential source of RS could be protein complexes interacting with the DNA during $\mathrm{S}$ phase that could slow down fork progression. A potential candidate for this would be the cohesin complexes. Whilst cohesin has been shown to have a role in preventing RSinduced DNA damage (30), we hypothesised that a c-Mycinduced increase in cohesin occupancy during G1 could slow down replisome progression during $\mathrm{S}$ phase as suggested in Kanke et al (31) and Morales et al (32). We therefore analysed the fraction of chromatin bound cohesin subunits Smc1 and Smc3 by Immunofluorescence (IF) of pre-extracted samples, in cells released from G0/G1 with and without c-Myc. These data show that higher levels of Smc1 and Smc3 are detected on chromatin in c-Myc-activated cells both in G1 and in S phase (Figure 2a, S3a). This was confirmed in asynchronous cell populations (Figure S3b) and by chromatin preparations followed by Western blot analysis (Figure 2b).

Our IF analysis on pre-extracted nuclei together with the chromatin preparation and Western blot analysis establish an overall increase in chromatin occupancy of the cohesin subunits Smc1 and Smc3, but do not reveal where these accumulate in the genome. To investigate if this c-Myc-dependent increase in chromatin bound cohesin accumulates at specific sites, we established genome-wide binding of the cohesin component Smc1 by ChIPseq in cells with activated c-Myc or control (Figure 2c-e). We performed these experiments at $48 \mathrm{hr}$ after c-Myc activation, when we observe consistent levels of RS (Figure S1k), and no obvious differences in cell cycle distribution between control and c-Myc-activated cells (Figure S1h). These experiments show that cohesin accumulates at 50,493 sites in c-Myc cells compared to 43,906 in control (Figure 2d, see set size). In particular, while the 
bioRxiv preprint doi: https://doi.org/10.1101/2021.07.25.453647; this version posted July 26, 2021. The copyright holder for this preprint (which was not certified by peer review) is the author/funder, who has granted bioRxiv a license to display the preprint in perpetuity. It is made available under aCC-BY 4.0 International license.

a

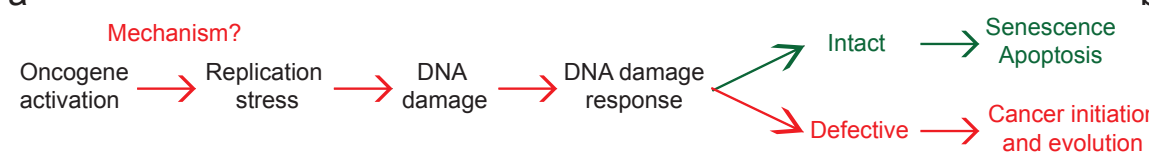

b

C

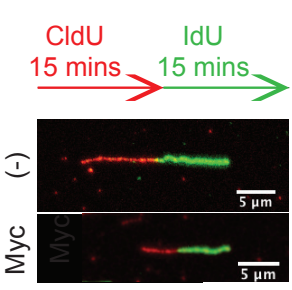

d

e

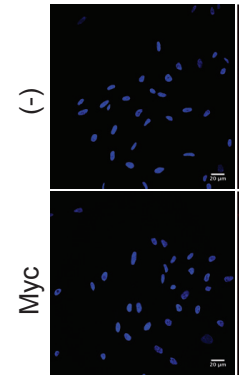

Hoechst

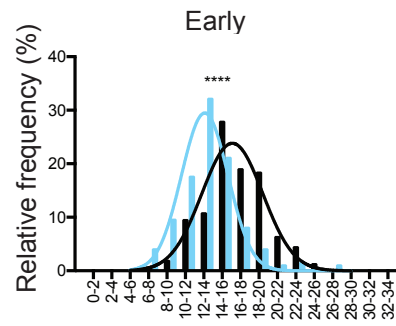

f

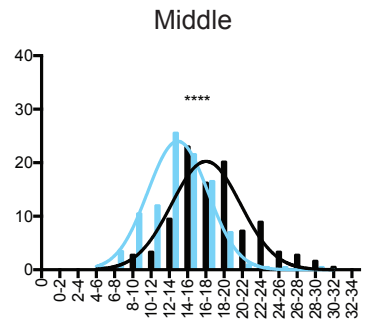

Replicative track length $(\mu \mathrm{m})$
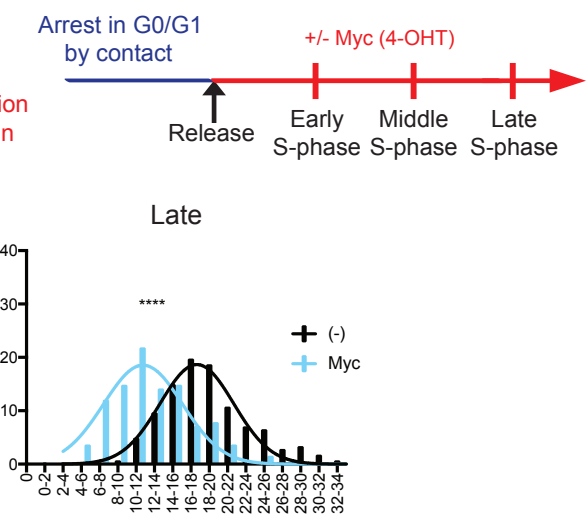

$(-)$
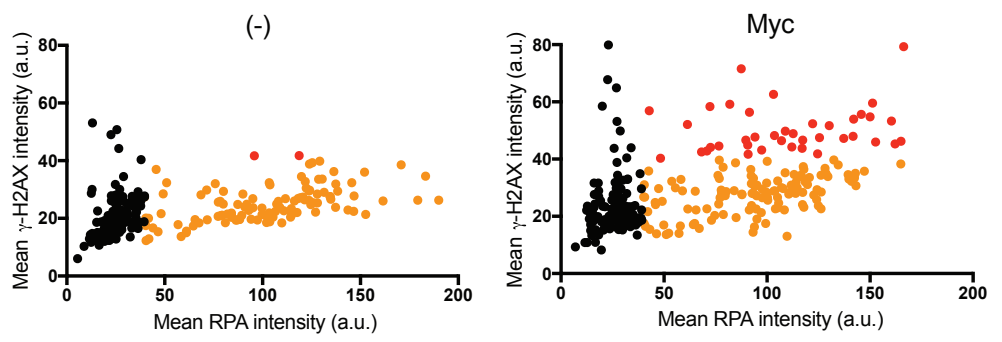

g

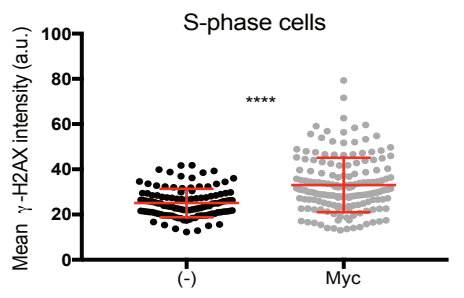

h

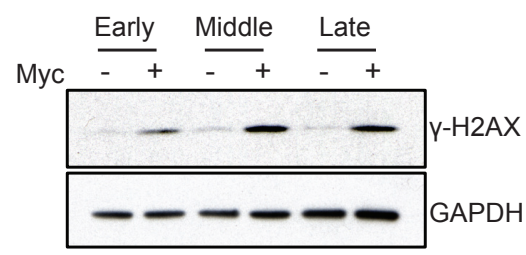

Fig. 1. c-Myc-induced replication stress and DNA damage depend on events in G1 phase. a) Schematic of known oncogene-induced replication stress mechanisms. b) Schematic of the synchronisation experiments for G1-S release. RPE1 c-Myc ER cells were left to grow to confluence, then trypsinised and plated in fresh medium. After cell spreading, $4 \mathrm{OH}-\mathrm{T}$ was added to induce c-Myc or left untreated as control. c) DNA fibre analysis of synchronised cells. Schematic showing the pulse labeling with the two nucleotide analogues. Immunofluorescence of representative fibres. d) Histograms reporting the distribution of fibre length for control and c-Myc-induced cells at the reported times after release from arrest; early $=18 \mathrm{hr}$, middle $=22 \mathrm{hr}$, late $=24 \mathrm{hr}$; $\mathrm{p}$-value ${ }^{\star \star \star *}<0.0001$ calculated with Mann-Whitney test. Representative of $\mathrm{n}=2$ experiments. e) Representative images of RPA and $\gamma \mathrm{H} 2 \mathrm{AX}$ immunofluorescence. f) Immunofluorescence staining of chromatin-bound RPA and $\gamma \mathrm{H} 2 \mathrm{AX}$ after release from confluence arrest. Scatter plot showing the intensity of RPA and $\gamma \mathrm{H} 2 \mathrm{AX}$ signal in single pre-extracted nuclei. Black=RPA negative cells, orange=RPA positive cells, red=RPA positive cells with higher $\gamma \mathrm{H} 2 \mathrm{AX}$ signal. Representative of $\mathrm{n}=2$ experiments. g) Graph showing $\gamma \mathrm{H} 2 \mathrm{AX}$ intensity in individual $\mathrm{S}$ phase cells plotted in $\mathrm{f}$ ). $\mathrm{p}$-value ${ }^{\star \star \star *}<0.0001 \mathrm{calculated}$ with Mann Whitney test. Representative of $\mathrm{n}=2$ experiments. $\mathrm{h}$ ) Western blot of $\gamma \mathrm{H} 2 \mathrm{AX}$ at the indicated time-points after release from $\mathrm{G} 1$ arrest, with and without c-Myc activation; early $=18 \mathrm{hr}$, middle $=22 \mathrm{hr}$, late $=24 \mathrm{hr}$; GAPDH is a loading control. Representative of $n=3$ experiments.

vast majority of peaks $(38,103)$ are common to control and cMyc-activated cells, 12,390 are unique for c-Myc and 5,803 are only present in the control (Figure 2d). Overall, the distribution of cohesin in genic and intergenic regions does not change upon c-Myc activation (Figure 2e). Motif analysis of the peaks in control shows enrichment of CTCF sites, which is in line with published data (23). Enrichment of CTCF sites can be detected in the peaks in common and in the c-Mycspecific peaks. These data suggest that the c-Myc-dependent increase in chromatin bound cohesin primarily accumulates at CTCF sites, in agreement with the reported location of cohesins on DNA $(23,24)$ (Figure 2d).

Next, we wanted to investigate if the increase in cohesin chromatin occupancy contributes to c-Myc-induced RS. We tested this by reducing the levels of cohesins on DNA in cells experiencing oncogenic c-Myc activity by targeting the cohesin component Rad21. We used a non-efficient siRNA to ensure that the reduction of $\operatorname{Rad} 21$ would not cause cell cycle defects during the first S phase (Figure S3c). Analysis of Smc1 binding to chromatin confirms that $\operatorname{Rad} 21$ knockdown reduces the levels of chromatin-bound cohesins both in untreated and in c-Myc cells (Figure 3a and b). Importantly, the levels of Smc1 on chromatin in Rad21-depleted c-Myc cells are similar to the untreated control, allowing us to test if the increased chromatin binding of cohesins is at the basis of generating RS.

Reducing the levels of cohesin chromatin occupancy in cells experiencing oncogenic c-Myc increases DNA fibre length in 
bioRxiv preprint doi: https://doi.org/10.1101/2021.07.25.453647; this version posted July 26, 2021. The copyright holder for this preprint (which was not certified by peer review) is the author/funder, who has granted bioRxiv a license to display the preprint in perpetuity. It is made available under aCC-BY 4.0 International license.

a

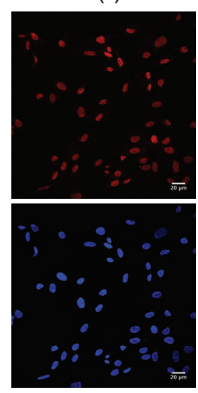

$(-)$

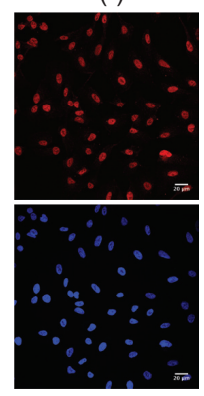

Myc

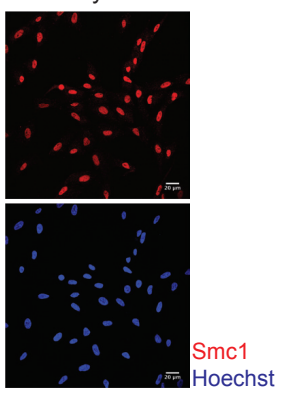

Myc

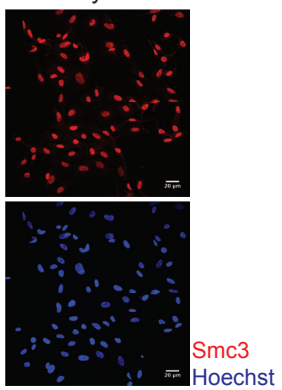

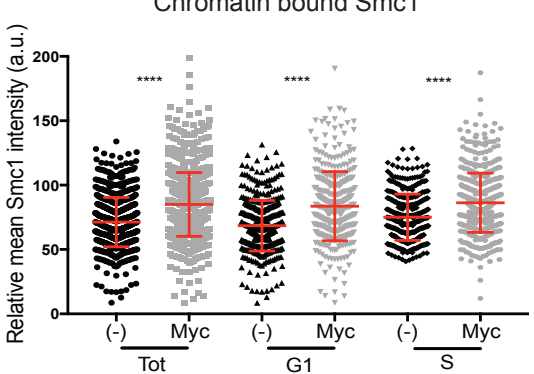

Chromatin bound Smc3

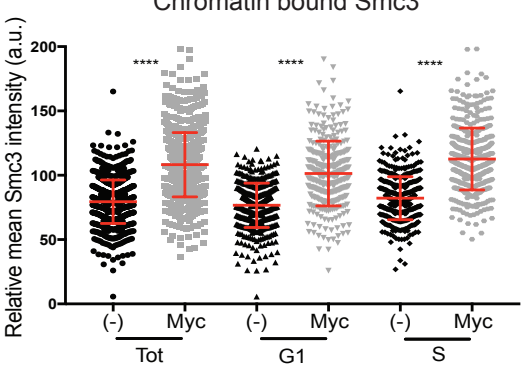

b

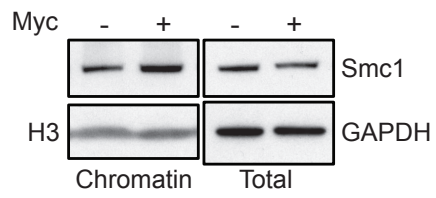

C

$361 \mathrm{~Kb}$
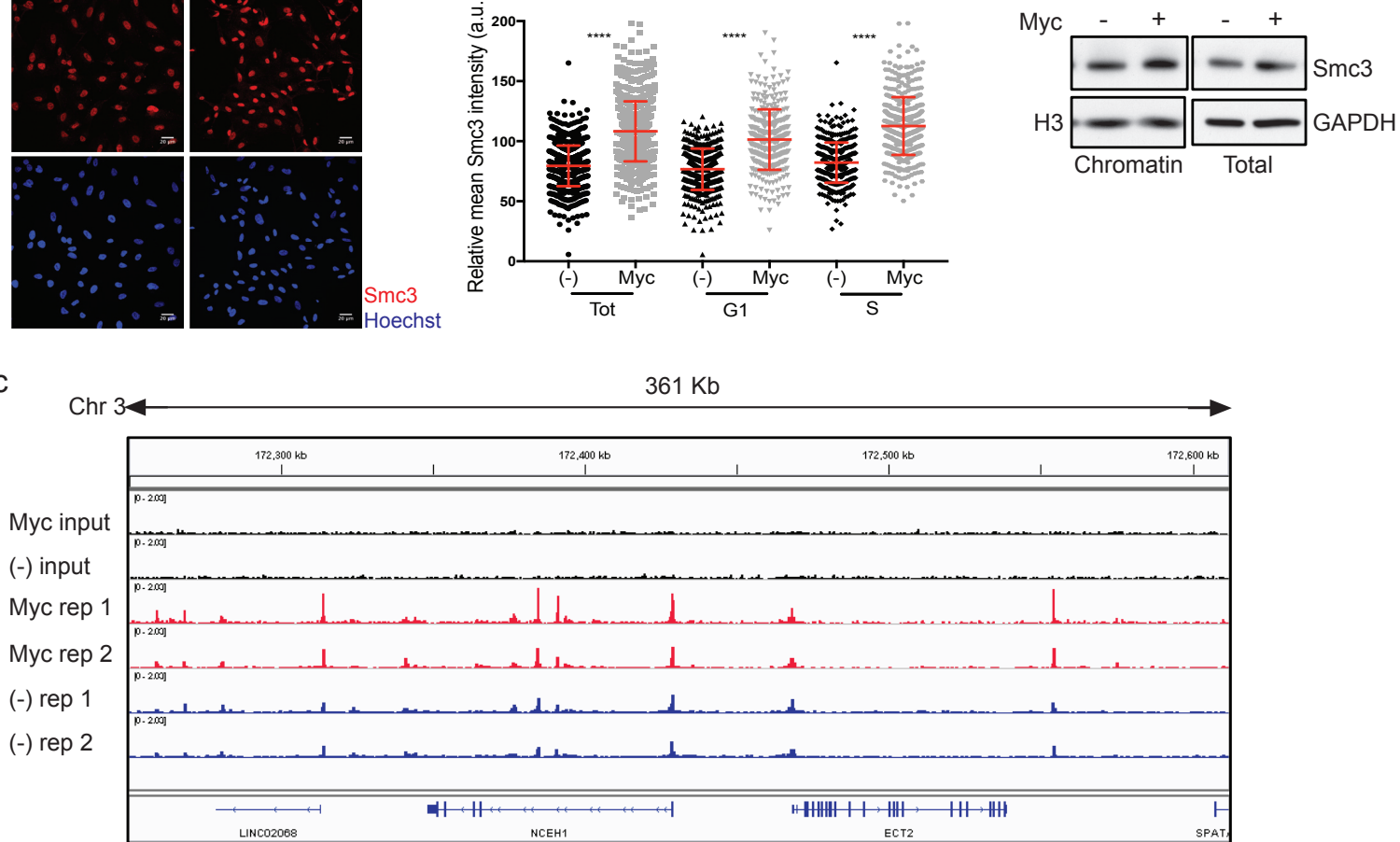

d

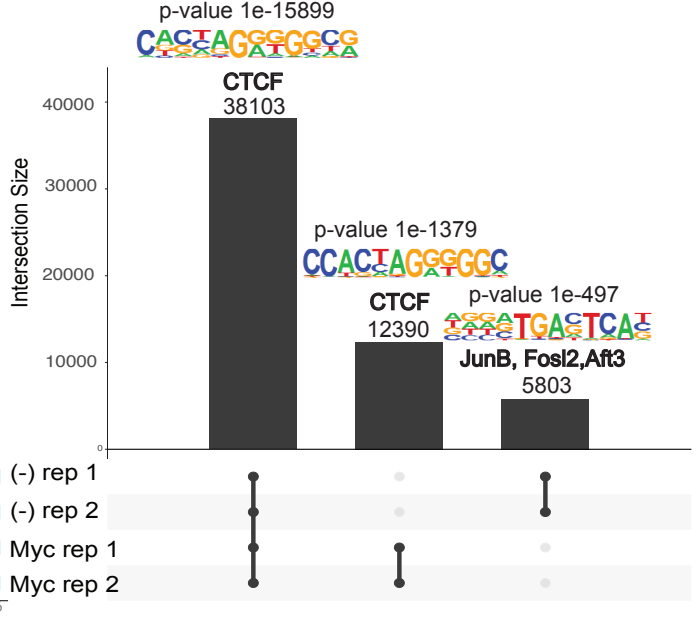

e

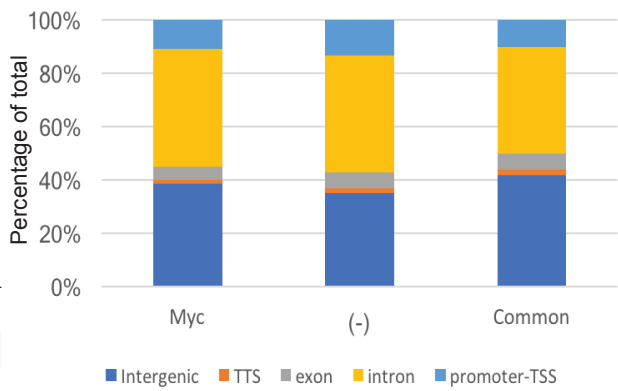

Set Size

Fig. 2. c-Myc activation increases cohesion chromatin occupancy in G1. a) Synchronised cells were released into the cell cycle and immunofluorescence of chromatinbound cohesin subunits Smc1 and Smc3 were performed at $18 \mathrm{hr}$ after release. Left panels; representative images of Smc1, Smc3 and Hoechst. Right: graph reporting the intensity of Smc1 and Smc3 signals in total, S phase and G1 phase single pre-extracted nuclei of untreated and c-Myc cells. p-value ${ }^{* * * *}<0.0001$ calculated with Mann-Whitney test. Pool of $n=3$ experiments. b) Western blot of chromatin preparations and total cell lysates in asynchronous population with and without c-Myc activation for $16 \mathrm{hr}$. GAPDH and $\mathrm{H} 3$ are loading controls. Representative of $\mathrm{n}=3$ experiments. c) Binding of Smc1 to the reported DNA loci in untreated and c-Myc-activated cells. Two repeats for each condition are represented. d) Graph representing the analysis of Smc1 binding distribution in c-Myc and untreated cells. Binding motif prediction with $p$-value for each group, along with the published similar consensus identified. e) Analysis of the genomic features of peak locations in c-Myc only, untreated only and common sites. 
bioRxiv preprint doi: https://doi.org/10.1101/2021.07.25.453647; this version posted July 26, 2021. The copyright holder for this preprint (which was not certified by peer review) is the author/funder, who has granted bioRxiv a license to display the preprint in perpetuity. It is made available under aCC-BY 4.0 International license.

a

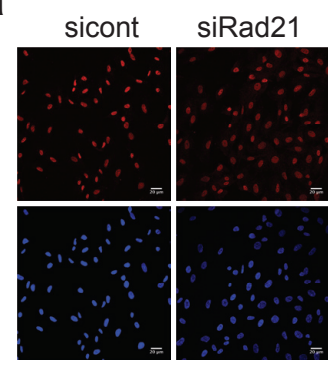

$(-)$

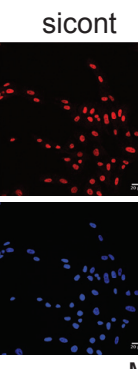

b

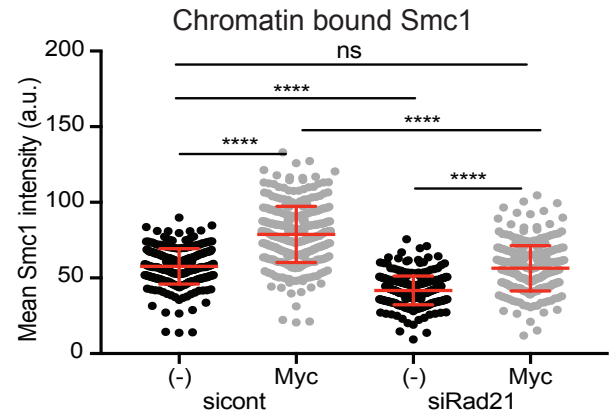

C

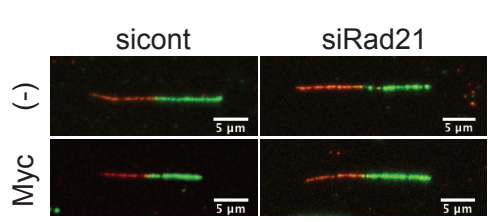

d

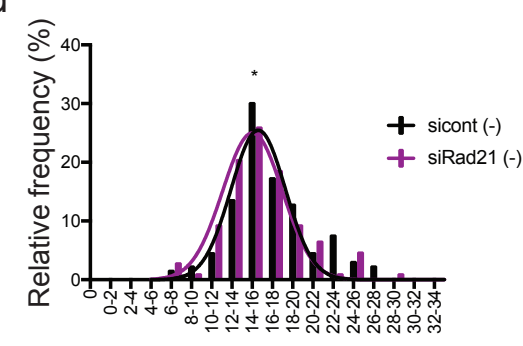

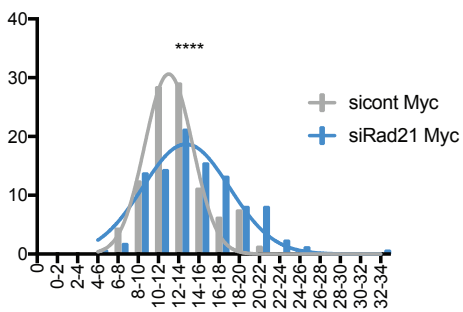

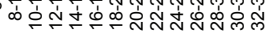

Replicative track length $(\mu \mathrm{m})$

e

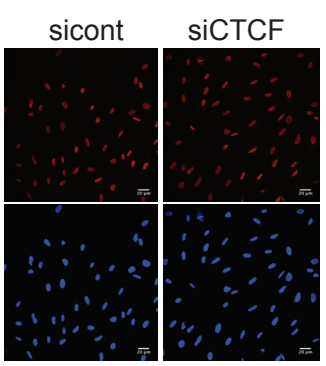

$(-)$ sicont

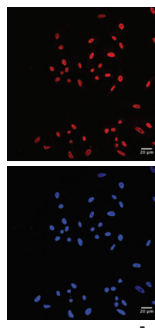

Myc

f
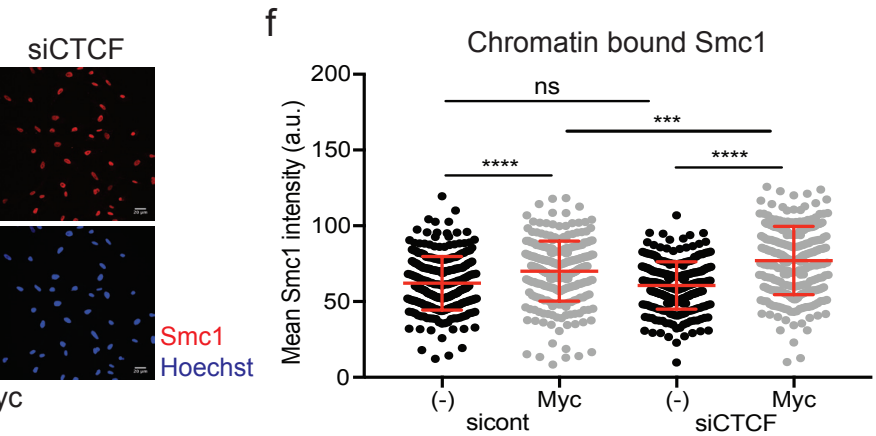

g

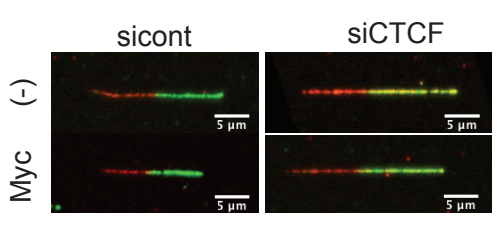

$\mathrm{h}$

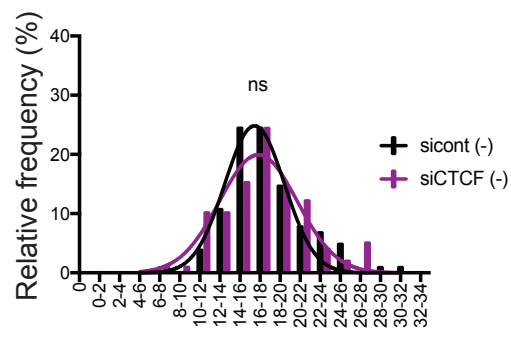

Replicative track length $(\mu \mathrm{m})$

Fig. 3. Reducing the levels of cohesin on chromatin at CTCF sites prevents c-Myc-induced replication stress. a) Immunofluorescence showing chromatin-bound Smc1 in synchronised sicontrol and siRad21 depleted cells at $20 \mathrm{hr}$ after release, with and without c-Myc activation. b) Graphs representing the intensity of chromatin-bound Smc1 signal in immunofluorescence. $p$-value ${ }^{\star * * *}<0.0001$ calculated with Mann-Whitney test. Representative of $n=3$ experiments. c) Immunofluorescence of representative fibres in synchronised sicontrol and siRad21 depleted cells at $20 \mathrm{hr}$ after release from G1. d) Histograms reporting the distribution of fibre length in synchronised sicontrol and siRad21 depleted cells. p-value ${ }^{\star \star \star *}<0.0001$ calculated with Mann-Whitney test. Representative of $n=3$ experiments. e) Immunofluorescence showing chromatin-bound Smc1 in synchronised sicontrol and siCTCF depleted cells at $20 \mathrm{hr}$ after release, with and without c-Myc activation. f) Graphs representing the intensity of Smc1 signal in the immunofluorescence. $p$-value ${ }^{* * *}<0.0001$ calculated with Mann-Whitney test. Representative of $n=3$ experiments. g) Immunofluorescence of representative fibres in synchronised sicontrol and siCTCF depleted cells at $20 \mathrm{hr}$ after release from G1. h) Histograms reporting the distribution of fibre length in synchronised sicontrol and siCTCF depleted cells. $p$-value ${ }^{\star \star \star *}<0.0001$ calculated with Mann-Whitney test. Representative of $n=3$ experiments. 
the first S-phase in both synchronous and asynchronous cell populations (Figure 3c and 3d, Figure S3d and S3e). Rad21 depletion did not affect the extent of replication origin firing and the cell cycle profiles (Figure S3f, S3g), nor the expression level of well-established c-Myc target genes (Figure S3h) supporting the idea that it is the increase of cohesins on DNA that contributes to RS. Next, we tested if the c-Mycdependent accumulation of cohesin specifically at CTCF sites was important for c-Myc-induced RS. Depleting CTCF (Figure S3i), completely rescued RS induced by c-Myc, without reducing the global amount of cohesins on DNA or affecting the cell cycle profiles (Figure 3e-h, S3j, S3k). We finally analysed the RS and DNA damage response activation in these cells, following Rad21 and CTCF depletion. We observed a decrease in both Chk1 phosphorylation and $\gamma \mathrm{H} 2 \mathrm{AX}$ levels compared to control silencing upon c-Myc activation, suggesting that in both cases RS-induced DNA damage was reduced (Figure S31, S3m).

Together these data indicate that the c-Myc-dependent increase in cohesins chromatin occupancy, likely at CTCF sites, causes a slowdown of replication forks to generate RS. To investigate how c-Myc could increase cohesin chromatin occupancy, we tested if its activation affects the expression levels of cohesin subunits and regulators. Smc1, Smc3 and $\operatorname{Rad} 21$ protein levels did not change significantly upon cMyc activation (Figure S4a). Interestingly, protein levels of the cohesin loader Mau2 increased upon c-Myc activation in both synchronised (Figure 4a) and asynchronous cells (Figure $4 \mathrm{~b}, \mathrm{~S} 4 \mathrm{~b})$, which corresponds to an increase in mRNA levels (Figure S4c, S4d). In vertebrates, cohesin loading requires NIPBL and Mau2 $(33,34)$. While NIPBL is the proper cohesin loader, Mau2 stabilises the protein levels of NIPBL $(23,35,36)$, therefore we analysed NIPBL levels in c-Myc-activated cells. Both Mau2 and NIPBL protein levels increase upon c-Myc activation (Figure S4b), while NIPBL mRNA does not change significantly (Figure S4d), suggesting that c-Myc increases Mau2 expression that in turn stabilises NIPBL.

To verify whether c-Myc-induced increase in cohesin chromatin occupancy could be partially due to increased loading via upregulating Mau2, we reduced Mau2 levels in c-Myc activated cells to control levels using a non-efficient siRNA (Figure 4c) and tested the presence of cohesins on chromatin and RS. Similar to Rad21 reduction, preventing the increase in Mau2 prevented excess cohesin loading onto chromatin (Figure 4d, e) and RS upon c-Myc activation in both synchronised (Figure 4f, g and S4e) and asynchronous cells (Figure S4f and S31, m). As for Rad21 knock down experiments, the extent of origin firing and cell cycle distribution is not affected by Mau2 depletion (Figure S4g). These data indicate that c-Myc-dependent increase in Mau2 levels could be at the basis of the increased loading of cohesins on chromatin, which causes RS during $\mathrm{S}$ phase.

To investigate if the c-Myc-dependent increase in Mau2 levels could contribute to the generation of RS we transiently expressed Mau2-GFP, or GFP as control, in RPE1 cells and analysed RPA phosphorylation, marker of RS, and $\gamma \mathrm{H} 2 \mathrm{AX}$, marker of DNA damage, by quantitative immunofluorescence and western blot (Figure S4h-m). Whilst both markers increase in IF in transfected cells, an increase in phosphorylation of RPA is particularly pronounced in IF and in total lysates. These data suggest that overexpression of Mau2 alone can cause some RS and RS-induced DNA damage.

We finally tested whether this mechanism of c-Myc-induced RS contributes to RS in cancer cells (Figure 4h-k). We selected a couple of lung cancer cell lines expressing different levels of c-Myc and measured the length of DNA fibres to evaluate the presence of RS. We observed reduced fibre length in the H1299 cell line compare to the A549 cells, which correlates with higher levels of c-Myc in H1299 cells (Figure $4 \mathrm{~h}, 4 \mathrm{i}$ ). To establish if a reduction in cohesins can rescue RS levels we depleted Rad21 (Figure S4n) and measured DNA fibre length in both cell lines (Figure $4 \mathrm{j}, \mathrm{k}$ and S4o). Rad21 depletion increased fibre length only in the H1299 cells, where c-Myc is highly expressed, but not in A549 cells, supporting a causative role for cohesins in RS, which is in the agreement with our findings. Interestingly depletion of $\operatorname{Rad} 21$ in the A549 cells, which do not experience RS, partially reduces fibre length. This suggests a protective role for cohesins in preventing RS, which is in agreement with reported work, supporting a double-edge involvement of cohesins in RS.

Our data show that a c-Myc-induced increase in cohesins on the DNA contributes to the induction of RS. This is different from previously reported mechanisms of oncogeneinduced RS, which are linked to deregulation of replication origin usage and/or transcription/replication interference. We show that the c-Myc-dependent accumulation of cohesins on chromatin, most likely at CTCF sites, can cause RS. Our data indicates that the levels of the cohesin loader Mau2 are upregulated by c-Myc activity, and that overexpression of Mau2 alone can cause RS, providing a potential mechanism through which c-Myc affects cohesin regulation. Overall, our data show that excessive cohesins on chromatin can interfere with the progression of replication forks, thus contributing to oncogene-induced RS. Our findings are surprising in light of previous work which indicates an important role for cohesins in preventing RS and DNA damage $(37,38)$. Based on our data we speculate that whilst the presence of cohesins during $S$ phase is required to protect stalled forks and repair damaged DNA, excessive cohesin accumulation in an oncogenic context can interfere with the progression of the replisome. This is in agreement with recently published work in mammalian cells which shows that increased presence of cohesins on DNA slows down fork progression (32) and with work in yeast, which shows that DNA damage accumulates in SMCrich genomic regions during replication (39). With c-Myc activation being a crucial event in many human cancers, identifying the mechanisms through which this oncogene promotes RS provides critical insights into cancer biology and therapy.

\section{Methods}

Sequencing data have been deposited in GEO under accession code GSE146766 
bioRxiv preprint doi: https://doi.org/10.1101/2021.07.25.453647; this version posted July 26, 2021. The copyright holder for this preprint (which was not certified by peer review) is the author/funder, who has granted bioRxiv a license to display the preprint in perpetuity. It is made available under aCC-BY 4.0 International license.

a

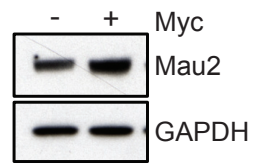

G1 release

d

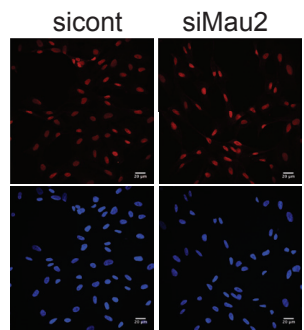

$(-)$

b

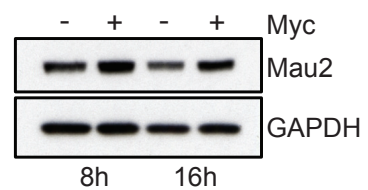

Asynchonous
siMau2

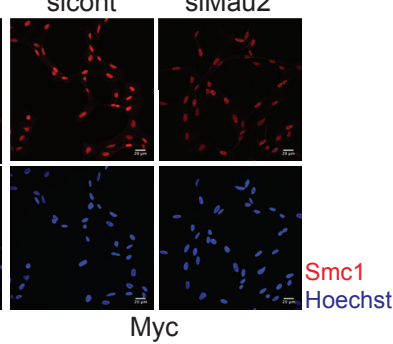

C

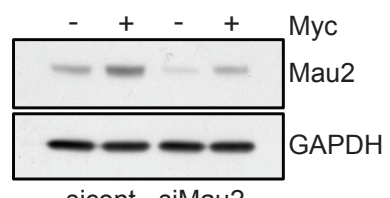

sicont siMau2

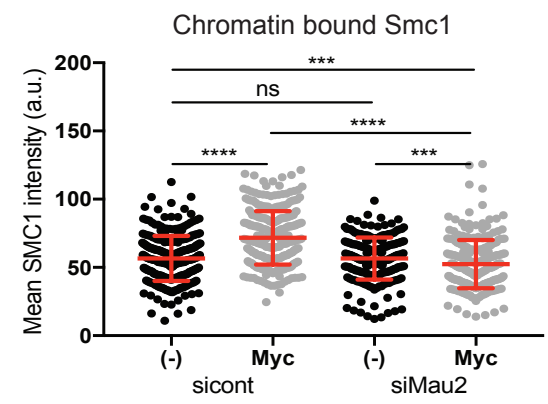

f
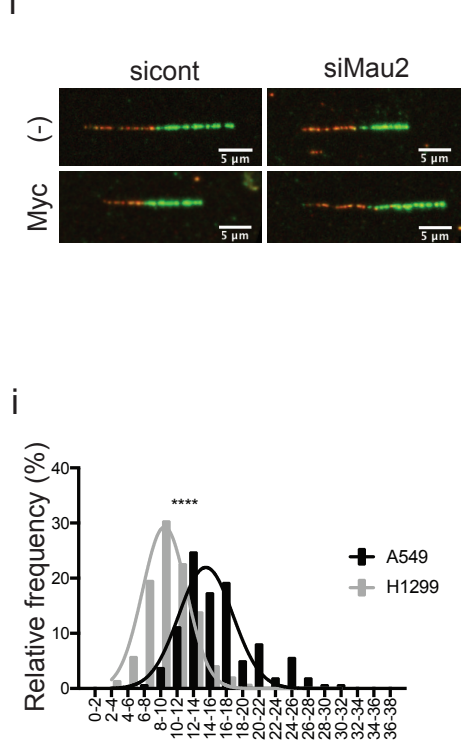

Replicative track length $(\mu \mathrm{m})$ g

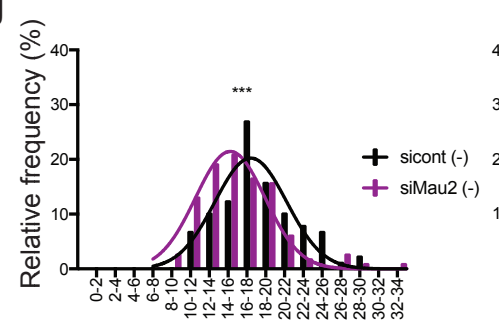

$\mathrm{h}$

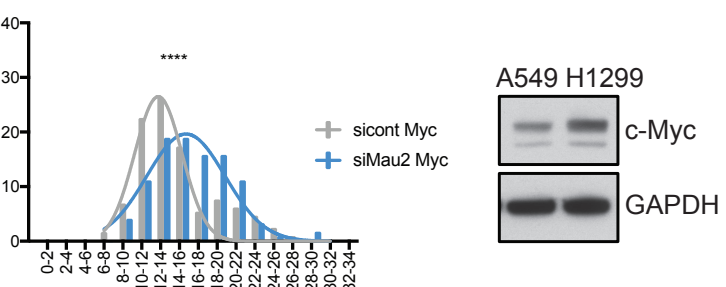

Replicative track length $(\mu \mathrm{m})$

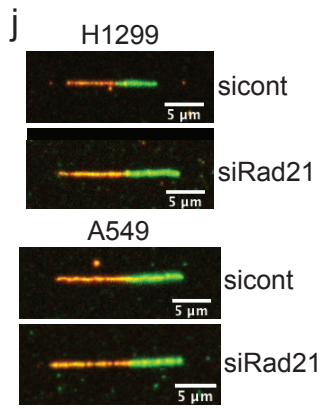

k
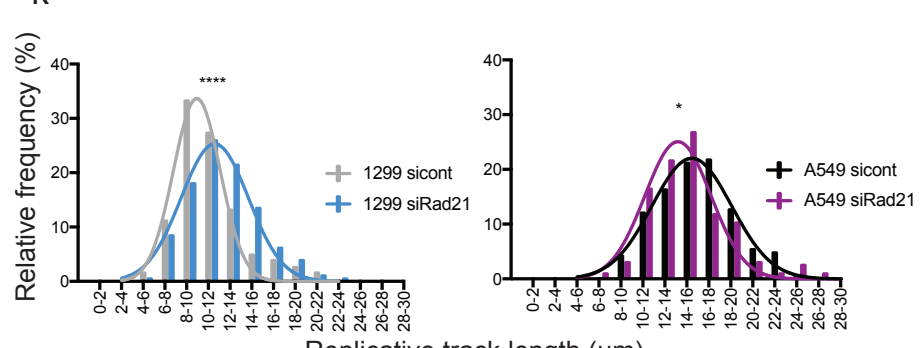

Replicative track length $(\mu \mathrm{m})$

Fig. 4. Reducing the levels of cohesin loader Mau2 prevents c-Myc-induced replication stress. a) Western blot showing total levels of the cohesin loader Mau2 in synchronised cells at $20 \mathrm{hr}$ after release, with and without c-Myc activation. Representative of $\mathrm{n}=3$ experiments. GAPDH is a loading control. b) Western blot showing total levels of the cohesin loader Mau2 in asynchronous population with and without c-Myc activation for the indicated timepoints. Representative of $n=2$ experiments. GAPDH is a loading control. c) Western blot showing Mau2 knock-down in synchronised cells at $20 \mathrm{hr}$ after release, with and without c-Myc activation. Representative of $\mathrm{n}=3$ experiments. GAPDH is a loading control. d) Immunofluorescence showing chromatin-bound Smc1 in synchronised sicontrol and siMau2 depleted cells at 20 hr after release, with and without c-Myc activation. e) Graphs representing the intensity of chromatin-bound Smc1 signal in the immunofluorescence. $p$-value ${ }^{\star * \star *}<0.0001,{ }^{* * *}=0.0001$ calculated with Mann-Whitney test. Representative of $n=2$ experiments. f) Immunofluorescence of representative fibres in synchronised sicontrol and siMau2 depleted cells at 20 hr after release from G1. g) Histograms reporting the distribution of fibre length in synchronised sicontrol and siMau2 depleted cells. p-value ${ }^{\star \star \star *}<0.0001$ calculated with MannWhitney test. Representative of $n=3$ experiments. h) Western blot showing total levels of c-Myc in A549 and H1299 cells. Representative of $n=3$ experiments. GAPDH is a loading control. i) Histograms reporting the distribution of fibre length in A549 and H1299 cells. p-value ${ }^{\star \star \star *}<0.0001$ calculated with Mann-Whitney test. Representative of $n=3$ experiments. j) Immunofluorescence of representative fibres in A549 and H1299 cells after Rad21 depletion. k) Histograms reporting the distribution of fibre length in A549 and $\mathrm{H} 1299$ cells after Rad21 depletion. $p$-value ${ }^{\star}=0.0356,{ }^{\star \star \star \star}<0.0001$ calculated with Mann-Whitney test. Representative of $n=3$ experiments. 
Cell culture and treatments. Cell lines used were immortalized hTERT human Retinal Pigment Epithelia 1 (ATCC CRL-4000) c-Myc-ER cells (previously described in (26)) and Retinal Pigment Epithelia 1 (ATCC CRL-4000) ER empty. Cells were cultured in phenol red free DMEM/F12 media supplemented with $10 \%$ charcoal-treated fetal bovine serum, $1 \%$ penicillin/streptomycin (Gibco) and 3\% sodium bicarbonate (Gibco). Cells were maintained in Puromycin $(2 \mu \mathrm{g} / \mathrm{ml})$. Cells were treated with 4-hydroxytamoxyfen (4OH-T) $(100 \mathrm{nM})$, with HU overnight $(2 \mathrm{mM})$ and for $4 \mathrm{hr}(0.2 \mathrm{mM})$, with Nocodazole for $8 \mathrm{hr}(200 \mathrm{ng} / \mathrm{ml})$ and with Palbociclib for $24 \mathrm{hr}(150 \mathrm{nM})$. RPE1 h-TERT (ATCC CRL-4000) cells were cultured in DMEM/F12 media supplemented with $10 \%$ fetal bovine serum, $1 \%$ penicillin/streptomycin (Gibco) and 3\% sodium bicarbonate (Gibco). A549 (ATCC CCL-185) cells were cultured with DMEM/F12 media supplemented with 10\% FBS and 1\% penicillin/streptomycin (Gibco). H1299 (ATCC CRL-5803) cells were cultured in RPMI media supplemented with $10 \%$ FBS and $1 \%$ penicillin/streptomycin (Gibco).

siRNA transfection. For siRNA transfection, Lipofectamine RNAiMAX (Invitrogen, 13778-075) was used following the manufacturer's instructions. Experiments were carried out $20 \mathrm{hr}$ after retro-transfection for synchronised cells. Unsynchronised cells were split $24 \mathrm{hr}$ after transfection and then used for experiments $24 \mathrm{hr}$ later. siRNA oligonucleotides with the following sequences, were used: siRad21 (GACCAAGGUUCCAUAUUAU), siCTCF (GGAGCCUGCCUGCCGUAGAAAUUTT), siMau2 (CCUCAGAACUUAACAUCUG). Non-targeting siRNA, referred as to sicont, (D-001206-13-05 siGENOME NonTargeting siRNA pool) was purchased from Dharmacon.

Plasmid transfection. For transient plasmid transfection, Lipofectamine 2000 (Invitrogen, 11668019) was used following the manufacturer's instructions. Plasmids used were pEGFP N1 and Scc4-Flag-EGFP (34).

Immunofluorescence. When appropriate cells were preextracted with ice-cold $0.2 \%$ triton solution in PBS $1 \mathrm{x}$ for $1 \mathrm{~min}$ and fixed for $20 \mathrm{~min}$ in formaldehyde solution $4 \%$. If the extraction protocol was not carried out, cells where permeabilised for $4 \mathrm{~min}$ in $0.2 \%$ triton solution in PBS $1 \mathrm{x}$ after fixation. Cells were blocked in blocking solution (1\% BSA, $0.2 \%$ Tween in PBS) for $1 \mathrm{hr}$ at room temperature. The incubation with the primary antibodies anti-RPA2 (Millipore RPA34-20 1:500), anti-PhosphoHistone H2A.X ( $\gamma$ H2AX) (Ser139) (Cell Signaling Technology $\gamma \mathrm{H} 2 \mathrm{AX}$ 20E3 1:250), anti-Smc1 (Bethyl laboratories A300-055A 1:1000), anti-Smc3 (Bethyl laboratories A300060A 1:2000), anti-Mcm7 (Santa Cruz Biotechnology sc56324 1:150), anti-RPA32 Phospho S4/S8 (Bethyl laboratories A300-245A 1:500) and anti-GFP (Abcam AB1218 1:1000) was carried out overnight. The following day the coverslips were incubated with secondary antibodies (Alexa Fluor® 488 goat anti-mouse 1:2000 and Alexa Fluor® 647 goat anti-rabbit 1:2000) for $2 \mathrm{hr}$ at room temperature. The cells were stained with Hoechst (Invitrogen) solution 1:10000 in PBS 1x. The coverslips were mounted on slides with mounting medium Fluoroshied (Sigma). Images were obtained with Leica SPE2 40x objective lens and processed with Fiji. For the quantitative analysis, between 200 and 300 cells were analysed per sample.

EdU and EU incorporation. Cells on coverslips were incubated with EdU (final concentration $10 \mu \mathrm{M}$ ) for $30 \mathrm{~min}$ and fixed in $4 \%$ formaldehyde solution. Cells were permeabilised in $0.2 \%$ triton for $5 \mathrm{~min}$ and incubated with Click-it reaction cocktail (Click-it Alexa Fluor 647 C-10424 Invitrogen) for $30 \mathrm{~min}$. Nuclei were stained with Hoechst (Invitrogen) solution 1:10000. The coverslips were mounted on slides with mounting medium Fluoroshied (Sigma). Images were obtained with Leica SPE2 40x objective lens and processed with Fiji.

For detection of global RNA synthesis levels by 5-Ethynyl Uridine (EU) staining, $1 \mathrm{mM}$ EU was added to cells for $1 \mathrm{hr}$ prior to collection. Cells were fixed in $4 \%$ formaldehyde. EU detection was performed using the Click-iT RNA Alexa Fluor 488 Imaging kit (Ther- moFisher, C10329) following manufacturer's instructions. Coverslips were rinsed for $2 \mathrm{~min}$ in Click-iT reaction rinse buffer and stained in Hoechst solution (1:10,000, Invitrogen H3570) for 5 min at room temperature. Fluoroshield (Sigma, F6182) was used for mounting on slides. Once dry, coverslips were sealed with nail varnish. Leica SPE2 using 40x objective lens and processed with Fiji.

Fibre analysis. Cells were labelled with $25 \mu \mathrm{M}$ CIdU for $15 \mathrm{~min}$ at $37^{\circ} \mathrm{C}$ and then with $250 \mu \mathrm{M} \mathrm{CO}$-equilibrated IdU (final concentration $250 \mu \mathrm{M}$ ) for $15 \mathrm{~min}$ at $37^{\circ} \mathrm{C}$. Fibre spreading and labelling was performed as in (40). The fibres were stained with primary antibodies (Rat anti-BrdU Abcam ab6326 1:250, Mouse anti-BrdU BD Biosciences $3475801: 100)$ overnight and with secondary antibodies (Alexafluor 555 goat anti-rat 1:500, Alexafluor 488 goat antimouse 1:500) for $1.5 \mathrm{hr}$. Images were obtained with Leica SPE2 63x objective lens and processed with Fiji. 100-200 fibres were measured for each experiment. Composite images were constructed to visualise red and green channels simultaneously. The 'line' tool in Fiji was used to measure length of DNA replicating fibres, which are characterised by the presence of consecutive red and green signals. Total amount of fibres (ongoing fibres, replication origins, replication terminations, stalled forks) and replication origins (characterised by a red track between two green tracks) were counted to quantify the percentage of origin firing.

Chromatin preparation. RPE-1 c-Myc ER cells were seeded in $10 \mathrm{~cm}$ dishes and c-Myc expression was activated upon tamoxifen treatment. Cells were harvested after $16 \mathrm{hr}$ of c-Myc activation and the chromatin was isolated with Chromatin Extraction Kit (ab117152, Abcam) according to the manufacture's protocol. The sonication was performed in a Diagenode Bioruptor ${ }^{\circledR}$ sonicator using the program $10 \mathrm{~min}$ : $30 \mathrm{~s}$ on, $30 \mathrm{~s}$ off. 
Western blot. Cell extracts were prepared in RIPA buffer (Tris pH $7.520 \mathrm{mM}, \mathrm{NaCl} 150 \mathrm{mM}$, EDTA $1 \mathrm{mM}$, EGTA $1 \mathrm{mM}$, NP-40 1\%, NaDoc 1\%), phosphatase inhibitor cocktail 2 and 3 (Sigma P5726 and P0044) 1:1000, and protease inhibitor cocktail (Sigma P8340) 1:1000. Primary antibodies used anti-Phospho-Histone H2A.X $(\gamma \mathrm{H} 2 \mathrm{AX})$ (Ser139) (Cell Signaling Technology g-H2AX 20E3 rabbit 1:250), anti-Scc4 (Mau2) (Abcam ab183033 1:500), anti -Idn3 (Nipbl) (Abcam ab106768 1:500), anti-Smc1 (Bethyl laboratories A300-055A rabbit 1:10000), anti-Smc3 (Bethyl laboratories A300-060A rabbit 1:10000), anti-Rad21 (Abcam ab992 1:2000), anti-CyclinE (Santa Cruz Biotechnology HE12 sc-247 1:1000), anti-CTCF (Chip-grade AB70303 Abcam 1:5000), anti-RPA32 Phospho S4/S8 (Bethyl laboratories A300-245A 1:1000), anti-RPA2 (Millipore RPA3420 1:1000), anti-c-Myc (Santa Cruz Biotechnology 9E10 sc40 1:1000), anti-CHK1 (Cell Signalling Technology 2360 1:1000), anti CHK1 Phospho S345 (Cell Signalling Technology 2341 1:250), anti-CHK2 (Cell Signalling Technology 2662 1:1000), anti CHK2 Phospho Thr68 (Cell Signalling Technology 2661 1:1000), anti-p21 (Cell Signalling Technology 2947 1:1000), anti-MDM2 (Cell Signalling Technology 86934 1:1000). Secondary antibodies used were goat anti-mouse IgG HRP conjugate (Thermofisher Scientific PA1-74421 1:4000) and goat anti rabbit IgG HRP conjugate (ThermoFisher Scientific 31460 1:4000). GAPDH (Genetex GT239 1:1000) and Vinculin (Abcam AB129002 1:10000) were used as loading controls.

Flow cytometry. For analysis of DNA content by propidium iodide (PI) staining, cells were collected by trypsinisation and fixed in $70 \%$ ethanol at $-20^{\circ} \mathrm{C}$ overnight. After centrifugation, the cell pellet was washed with PBS and resuspended in $100 \mathrm{mg} / \mathrm{ml} \mathrm{RNaseA}$ and $50 \mathrm{mg} / \mathrm{ml}$ propidium iodide in PBS, and incubated at $4^{\circ} \mathrm{C}$ overnight. Samples were measured on a BD LSRII flow cytometer using DIVA software (BD) and analysed using FlowJo software.

Survival assay. Cells were treated for $48 \mathrm{hr}$ with $4 \mathrm{OH}-\mathrm{T}$ or left untreated. The same volume of cell suspension was replated in $5 \mathrm{~cm}$ dishes and colonies were left to grow for one week. Cells were finally fixed and stained in $70 \% \mathrm{EtOH}$ and $0.5 \%$ Methylene blue.

CHiPseq. Cells were cultured in $15 \mathrm{~cm}$ dishes for $48 \mathrm{hr}$ with or without the addition of $4 \mathrm{OH}-\mathrm{T}$. Cells were then washed with 1x PBS and crosslinked in $10 \mathrm{ml}$ of $1 \%$ formaldehyde at RT for $10 \mathrm{~min}$. Quenching was carried out adding $1 \mathrm{ml}$ of $1.25 \mathrm{M}$ glycine for $10 \mathrm{~min}$ at RT. Cells were then scraped in PBS, spin down, resuspended in cold buffer A (100 mM Hepes pH8, 100 mM EDTA, 5 mM EGTA, 2.5\% triton) and rocked for $10 \mathrm{~min}$ at $4{ }^{\circ} \mathrm{C}$. The same step was repeated using cold buffer B (100mM Hepes pH8, 2M NaCl, 100mM EDTA, $5 \mathrm{mM}$ EGTA, $0.1 \%$ triton). Cells were resuspended in cold ChIP buffer ( $25 \mathrm{mM}$ tris/HCl pH8, $2 \mathrm{mM}$ EDTA, $150 \mathrm{mM}$ $\mathrm{NaCl}, 1 \%$ triton, $0.1 \%$ SDS) plus protease inhibitor cocktail (Sigma P8340) and sonicated at maximum output on a Bioruptor for $30 \mathrm{~s}$ on/30 s off for $30 \mathrm{~min}$ using Diagenode tubes. Sonication was checked on $1 \%$ agarose gel. After sonication, lysates where centrifuged for $15 \mathrm{~min}$ at maximum speed at $4{ }^{\circ} \mathrm{C}$. Protein A solution was prepared by resuspending beads in ChIP buffer (about 50\%) $1 \mu \mathrm{g} / \mu \mathrm{l} \mathrm{BSA}$ and rocking at $4^{\circ} \mathrm{C}$ for $15 \mathrm{~min}$. The supernatant (soluble chromatin) was transferred in new tubes and pre-cleared adding blocked protein A solution and rocking for $2 \mathrm{hr}$ at $4^{\circ} \mathrm{C}$. Cleared soluble chromatin was centrifuged for $4 \mathrm{~min}$ at $4000 \mathrm{rpm}$ at $4^{\circ} \mathrm{C}$. The supernatant was transferred in a new tube and $10 \mu \mathrm{l}$ was saved as input. The soluble chromatin was incubated overnight with $10 \mu \mathrm{g}$ of anti Smc1 (Bethyl laboratories A300055A rabbit). The following day $20 \mu \mathrm{l}$ protein A beads prepared as above, were added to chromatin, which was then rocked at $4^{\circ} \mathrm{C}$ for $2 \mathrm{hr}$. Beads were spin down for $2 \mathrm{~min}$ at $2000 \mathrm{rpm}$ and washed with ChIP buffer, wash solution 1 (25 mM Tris/HCl pH8, 2 mM EDTA, $500 \mathrm{mM} \mathrm{NaCl}, 1 \%$ triton, $0.1 \%$ SDS $)$, Wash solution $2(250 \mathrm{mM} \mathrm{LiCl}, 1 \% \mathrm{NP} 40$, $1 \% \mathrm{NaDOC}, 1 \mathrm{mM}$ EDTA, $10 \mathrm{mM}$ Tris/Hcl pH 8) and twice with TE. TE was then removed and elution buffer (1\% SDS, $100 \mathrm{mM}$ NaHCO3) was added. All samples were incubated at $65^{\circ} \mathrm{C}$ overnight to reverse crosslinking. The day after, samples were purified using QIAquick PCR purification kit (QUIAGEN). The DNA was then diluted in ddH2O. QC was performed using the ThermoFisher Qubit and either the Agillent BioAnalyser or TapeStation. The DNA samples were normalised and prepared into Illumina compatible libraries using the KAPA HyperPrep kit according to the manufacturer's instructions. The libraries were pooled to $4 \mathrm{nM}$ and sequencing was performed on the HiSeq 4000 with at least 75 bp reads.

RTqPCR. RNA was extracted using RNeasy plus mini kit Qiagen. Before column purification cell pellets were vortexed for $30 \mathrm{~s}$ in RLT buffer $+1 \% \beta$-mercaptoethanol. RTqPCR was carried out using Mesa Blue mastermix (Eurogentec). All reactions were normalised to Gapdh as a control.

Statistics. Statistical significance was analysed using MannWhitney test and Student's t-test. When appropriate, S phase cells were defined as the portion of cells where RPA2 $>40$ a.u. (Figure 1f, 1g), RPA2 $>50$ a.u. (Figure 2a, S3a), RPA2 $>25$ a.u. (Figure S1q, S1r) RPA2 $>18$ a.u. (Figure S3b).

\section{ACKNOWLEDGEMENTS}

We are grateful to Dr. F. Uhlmann for advice. We thank the Crick Institute Advanced Sequencing Facility for the ChIPseq. We thank Dr. J-M. Peters for kindly providing GFP-Mau2 plasmid. We would also like to thank to Dr. F. Peri for help with statistical analysis. This work was supported by core funding to the MRC-UCL University Unit (Ref. MCEXG0800785) and funded by R.d.B.'s Cancer Research UK Programme Foundation Award.

\section{Bibliography}

1. V G Gorgoulis, L V F Vassiliou, P Karakaidos, P Zacharatos, A Kotsinas, T Liloglou, M Venere, R A Ditullio, N G Kastrinakis, B Levy, D Kletsas, A Yoneta, M Herlyn, C Kittas, and T D Halazonetis. Activation of the DNA damage checkpoint and genomic instability in human precancerous lesions. Nature, 434(7035):907-13, apr 2005. ISSN 1476-4687. doi: 10.1038 /nature 03485 .

2. C V Dang. MYC on the path to cancer. Cell, 149(1):22-35, 2012. doi: 10.1016/j.cell.2012. 03.003.

3. R A Burrell, S E McClelland, D Endesfelder, P Groth, M C Weller, N Shaikh, E Domingo, N Kanu, S M Dewhurst, E Gronroos, S K Chew, A J Rowan, A Schenk, M Sheffer, M Howell, M Kschischo, A Behrens, T Helleday, J Bartek, I P Tomlinson, and C Swanton. Replication 
bioRxiv preprint doi: https://doi.org/10.1101/2021.07.25.453647; this version posted July 26, 2021. The copyright holder for this preprint (which was not certified by peer review) is the author/funder, who has granted bioRxiv a license to display the preprint in perpetuity. It is made available under aCC-BY 4.0 International license.

stress links structural and numerical cancer chromosomal instability. Nature, 494(7438): 492-496, feb 2013. ISSN 1476-4687. doi: 10.1038/nature11935.

4. D Dominguez-Sola, C Y Ying, C Grandori, L Ruggiero, B Chen, Muyang Li, D A Galloway, W Gu, J Gautier, and R Dalla-Favera. Non-transcriptional control of DNA replication by c-Myc. Nature, 448(7152):445-51, jul 2007. ISSN 1476-4687. doi: 10.1038/nature05953.

5. S V Srinivasan, D Dominguez-Sola, L C Wang, O Hyrien, and J Gautier. Cdc45 is a critical effector of myc-dependent DNA replication stress. Cell reports, 3(5):1629-39, may 2013. ISSN 2211-1247. doi: 10.1016/j.celrep.2013.04.002.

6. S A Hills and J F X Diffley. DNA replication and oncogene-induced replicative stress. Current biology : CB, 24(10):R435-44, may 2014. ISSN 1879-0445. doi: 10.1016/j.cub.2014.04.012.

7. R M Jones, O Mortusewicz, I Afzal, M Lorvellec, P García, T Helleday, and E Petermann. Increased replication initiation and conflicts with transcription underlie Cyclin Einduced replication stress. Oncogene, 32(32):3744-53, aug 2013. ISSN 1476-5594. doi: 10.1038/onc.2012.387.

8. P Kotsantis, L M Silva, S Irmscher, R M Jones, L Folkes, N Gromak, and E Petermann. Increased global transcription activity as a mechanism of replication stress in cancer. Nature communications, 7:13087, 2016. ISSN 2041-1723. doi: 10.1038/ncomms 13087 .

9. S Parajuli, D C Teasley, B Murali, J Jackson, A Vindigni, and S A Stewart. Human ribonuclease $\mathrm{H} 1$ resolves R-loops and thereby enables progression of the DNA replication fork. The Journal of biological chemistry, 292(37):15216-15224, 2017. ISSN 1083-351X. doi: 10.1074/jbc.M117.787473.

10. S Ekholm-Reed, J Méndez, D Tedesco, A Zetterberg, B Stillman, and S I Reed. Deregulation of cyclin $E$ in human cells interferes with prereplication complex assembly. Journal of Cell Biology, 2004. ISSN 00219525. doi: 10.1083/jcb.200404092.

11. $M$ Macheret and $T D$ Halazonetis. DNA replication stress as a hallmark of cancer. Annual review of pathology, 10(1):425-48, 2015. ISSN 1553-4014. doi: 10.1146/ annurev-pathol-012414-040424.

12. S Ekholm-Reed, J Méndez, D Tedesco, A Zetterberg, B Stillman, and S I Reed. Deregulation of cyclin $\mathrm{E}$ in human cells interferes with prereplication complex assembly. The Journal of cell biology, 165(6):789-800, jun 2004. ISSN 0021-9525. doi: 10.1083/jcb.200404092.

13. C Y Lin, J Lovén, P B Rahl, R M Paranal, C B Burge, J E Bradner, T I Lee, and R A Young. Transcriptional amplification in tumor cells with elevated c-Myc. Cell, 151(1):56-67, sep 2012. ISSN 1097-4172. doi: 10.1016/j.cell.2012.08.026.

14. F Uhlmann. SMC complexes: from DNA to chromosomes. Nature reviews. Molecular cell biology, 17(7):399-412, 2016. ISSN 1471-0080. doi: 10.1038/nrm.2016.30.

15. A Tedeschi, G Wutz, S Huet, M Jaritz, A Wuensche, E Schirghuber, I F Davidson, W Tang, D A Cisneros, V Bhaskara, T Nishiyama, A Vaziri, A Wutz, J Ellenberg, and J M Peters. Wap is an essential regulator of chromatin structure and chromosome segregation. Nature, 501 (7468):564-8, sep 2013. ISSN 1476-4687. doi: 10.1038/nature12471.

16. D Gerlich, B Koch, F Dupeux, J M Peters, and J Ellenberg. Live-cell imaging reveals a stable cohesin-chromatin interaction after but not before DNA replication. Current biology : $C B, 16(15): 1571-8$, aug 2006. ISSN 0960-9822. doi: 10.1016/j.cub.2006.06.068.

17. J Zhang, X Shi, Y Li, B J Kim, J Jia, Z Huang, T Yang, X Fu, S Y Jung, Y Wang, P Zhang, $\mathrm{S} T \mathrm{Kim}, \mathrm{X}$ Pan, and J Qin. Acetylation of $\mathrm{Smc3}$ by Eco1 is required for $\mathrm{S}$ phase sister chromatid cohesion in both human and yeast. Molecular cell, 31(1):143-51, jul 2008. ISSN 1097-4164. doi: 10.1016/j.molcel.2008.06.006.

18. B D Rowland, M B Roig, T Nishino, A Kurze, P Uluocak, A Mishra, F Beckouet, P Underwood, J Metson, R Imre, K Mechtler, V L Katis, and K Nasmyth. Building sister chromatid cohesion: smc3 acetylation counteracts an antiestablishment activity. Mol Cell, 33(6):763774, 2009. doi: 10.1016/j.molcel.2009.02.028.

19. A Lengronne, Y Katou, S Mori, S Yokobayashi, G P Kelly, T Itoh, Y Watanabe, K Shirahige, and $\mathrm{F}$ Uhlmann. Cohesin relocation from sites of chromosomal loading to places of convergent transcription. Nature, 430(6999):573-8, jul 2004. ISSN 1476-4687. doi: 10.1038 /nature02742.

20. G A Busslinger, R R Stocsits, P van der Lelij, E Axelsson, A Tedeschi, N Galjart, and J M Peters. Cohesin is positioned in mammalian genomes by transcription, CTCF and Wapl. Nature, 544(7651):503-507, 2017. ISSN 1476-4687. doi: 10.1038/nature22063.

21. B D Pope, T Ryba, V Dileep, F Yue, W Wu, O Denas, D L Vera, Y Wang, R S Hansen, T K Canfield, R E Thurman, Y Cheng, G Gülsoy, J H Dennis, M P Snyder, J A Stamatoyannopoulos, J Taylor, R C Hardison, T Kahveci, B Ren, and D M Gilbert. Topologically associating domains are stable units of replication-timing regulation. Nature, 515(7527): 402-5, nov 2014. ISSN 1476-4687. doi: 10.1038/nature13986.

22. V Dileep, F Ay, J Sima, D L Vera, W S Noble, and D M Gilbert. Topologically associating domains and their long-range contacts are established during early $\mathrm{G} 1$ coincident with the establishment of the replication-timing program. Genome research, 25(8):1104-13, aug 2015. ISSN 1549-5469. doi: 10.1101/gr.183699.114.

23. K S Wendt, K Yoshida, T Itoh, M Bando, B Koch, E Schirghuber, S Tsutsumi, G Nagae, K Ishihara, T Mishiro, K Yahata, F Imamoto, H Aburatani, M Nakao, N Imamoto, $\mathrm{K}$ Maeshima, K Shirahige, and J M Peters. Cohesin mediates transcriptional insulation by CCCTC-binding factor. Nature, 451(7180):796-801, feb 2008. ISSN 1476-4687. doi: 10.1038/nature06634

24. G Wutz, C Várnai, K Nagasaka, D A Cisneros, R R Stocsits, W Tang, S Schoenfelder, G Jessberger, M Muhar, M J Hossain, N Walther, B Koch, M Kueblbeck, J Ellenberg, J Zuber, $\mathrm{P}$ Fraser, and $\mathrm{J} \mathrm{M}$ Peters. Topologically associating domains and chromatin loops depend on cohesin and are regulated by CTCF, WAPL, and PDS5 proteins. The EMBO journal, 36(24):3573-3599, 2017. ISSN 1460-2075. doi: 10.15252/embj.201798004.

25. G Wutz, R Ladurner, B G St Hilaire, R R Stocsits, K Nagasaka, B Pignard, A Sanborn W Tang, C Várnai, M $P$ Ivanov, S Schoenfelder, $P$ van der Lelij, X Huang, G Dürnberger, E Roitinger, K Mechtler, I F Davidson, P J Fraser, E Lieberman-Aiden, and J M Peters. ESCO1 and CTCF enable formation of long chromatin loops by protecting cohesinSTAG1 from WAPL. eLife, 2020. ISSN 2050-084X. doi: 10.1101/779058.

26. C Bertoli, A E Herlihy, B R Pennycook, J Kriston-Vizi, and R A M de Bruin. Sustained E2FDependent Transcription Is a Key Mechanism to Prevent Replication-Stress-Induced DNA Damage. Cell reports, 15(7):1412-1422, 2016. ISSN 2211-1247. doi: 10.1016/j.celrep. 2016.04.036.

27. B R Pennycook, E Vesela, S Peripolli, T Singh, A R Barr, C Bertoli, and R A M de Bruin.
E2F-dependent transcription determines replication capacity and S phase length. Nature Communications, 2020. ISSN 20411723. doi: 10.1038/s41467-020-17146-z.

28. Eleanor Wendy Trotter and lain Michael Hagan. Release from cell cycle arrest with Cdk4/6 inhibitors generates highly synchronized cell cycle progression in human cell culture: Cdk4/6 Induction Synchronisation. Open Biology, 10(10), 2020. ISSN 20462441. doi: 10.1098/rsob.200200rsob200200.

29. M Macheret and T D Halazonetis. Intragenic origins due to short G1 phases underlie oncogene-induced DNA replication stress. Nature, 555(7694):112-116, 2018. ISSN 14764687. doi: $10.1038 /$ nature25507.

30. S Rohban, A Cerutti, M J Morelli, F d'Adda di Fagagna, and S Campaner. The cohesin complex prevents Myc-induced replication stress. Cell death \& disease, 2017. ISSN 20414889. doi: 10.1038/cddis.2017.345.

31. M Kanke, E Tahara, P J Huis In't Veld, and T Nishiyama. Cohesin acetylation and WaplPds5 oppositely regulate translocation of cohesin along DNA. The EMBO journal, 35(24): 2686-2698, 2016. ISSN 1460-2075. doi: 10.15252/embj.201695756.

32. C Morales, M Ruiz-Torres, S Rodríguez-Acebes, V Lafarga, M Rodríguez-Corsino, D Megías, D A Cisneros, J M Peters, J Méndez, and A Losada. PDS5 proteins are required for proper cohesin dynamics and participate in replication fork protection. Journal of Biological Chemistry, 2020. ISSN 1083351X. doi: 10.1074/jbc.RA119.011099.

33. R Ciosk, M Shirayama, A Shevchenko, T Tanaka, A Toth, A Shevchenko, and K Nasmyth Cohesin's binding to chromosomes depends on a separate complex consisting of Scc2 and Scc4 proteins. Molecular Cell, 2000. ISSN 10972765. doi: 10.1016/S1097-2765(00) 80420-7.

34. Erwan Watrin, Alexander Schleiffer, Koichi Tanaka, Frank Eisenhaber, Kim Nasmyth, and Jan Michael Peters. Human Scc4 Is Required for Cohesin Binding to Chromatin, SisterChromatid Cohesion, and Mitotic Progression. Current Biology, 16(9), 2006. ISSN 09609822. doi: 10.1016/j.cub.2006.03.049.

35. W C H Chao, Y Murayama, S Muñoz, A Costa, F Uhlmann, and M R Singleton. Structural Studies Reveal the Functional Modularity of the Scc2-Scc4 Cohesin Loader. Cell Reports, 2015. ISSN 22111247. doi: 10.1016/j.celrep.2015.06.071.

36. Ilaria Parenti, Farah Diab, Sara Ruiz Gil, Eskeatnaf Mulugeta, Valentina Casa, Riccardo Berutti, Rutger W.W. Brouwer, Valerie Dupé, Juliane Eckhold, Elisabeth Graf, Beatriz Puisac, Feliciano Ramos, Thomas Schwarzmayr, Macarena Moronta Gines, Thomas van Staveren, Wilfred F.J. van IJcken, Tim M. Strom, Juan Pié, Erwan Watrin, Frank J. Kaiser, and Kerstin S. Wendt. MAU2 and NIPBL Variants Impair the Heterodimerization of the Cohesin Loader Subunits and Cause Cornelia de Lange Syndrome. Cell Reports, 31(7), 2020. ISSN 22111247. doi: 10.1016/j.celrep.2020.107647.

37. L Strom, H B Lindroos, K Shirahige, and C Sjogren. Postreplicative recruitment of cohesin to double-strand breaks is required for DNA repair. Mol Cell, 16(6):1003-1015, 2004. doi: 10.1016/j.molcel.2004.11.026

38. C Frattini, S Villa-herna, R Jossen, Y Katou, K Shirahige, R Bermejo, S Villa-Hernández, $G$ Pellicanò, $R$ Jossen, $Y$ Katou, $K$ Shirahige, and $R$ Bermejo. Cohesin Ubiquitylation and Mobilization Facilitate Stalled Replication Fork Dynamics. Molecular Cell, 68(4):758772.e4, 2017. ISSN 10974164. doi: 10.1016/j.molcel.2017.10.012.

39. N E Minchell, A Keszthelyi, and J Baxter. Cohesin Causes Replicative DNA Damage by Trapping DNA Topological Stress. Molecular Cell, 2020. ISSN 10972765. doi: 10.1016/j. molcel.2020.03.013.

40. E Petermann, M Woodcock, and T Helleday. Chk1 promotes replication fork progression by controlling replication initiation. Proceedings of the National Academy of Sciences of the United States of America, 107(37):16090-5, sep 2010. ISSN 1091-6490. doi: 10.1073/pnas. 1005031107 


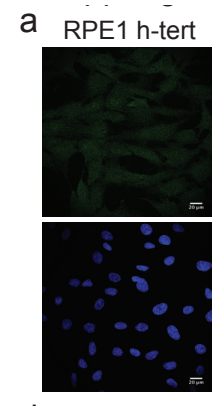

d
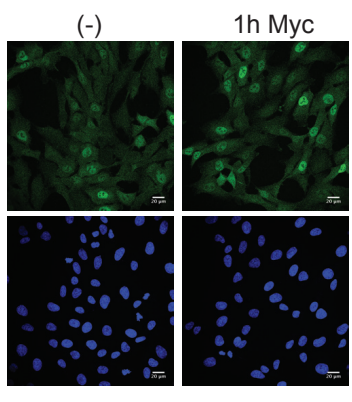

e

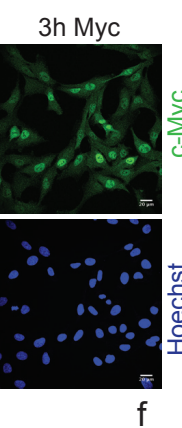

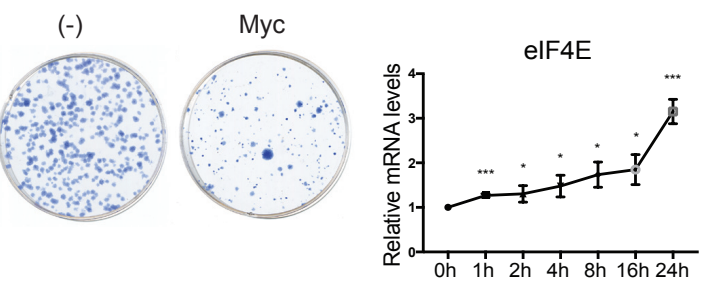

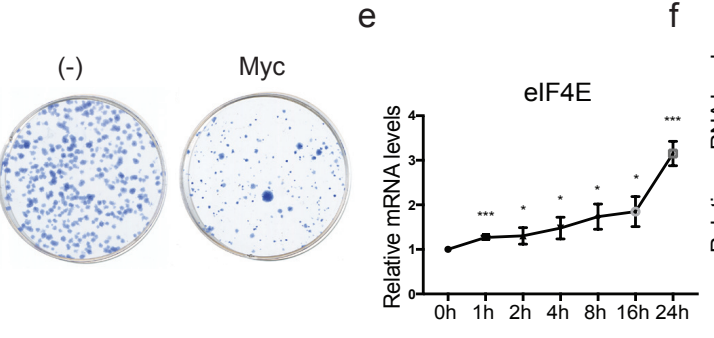

b
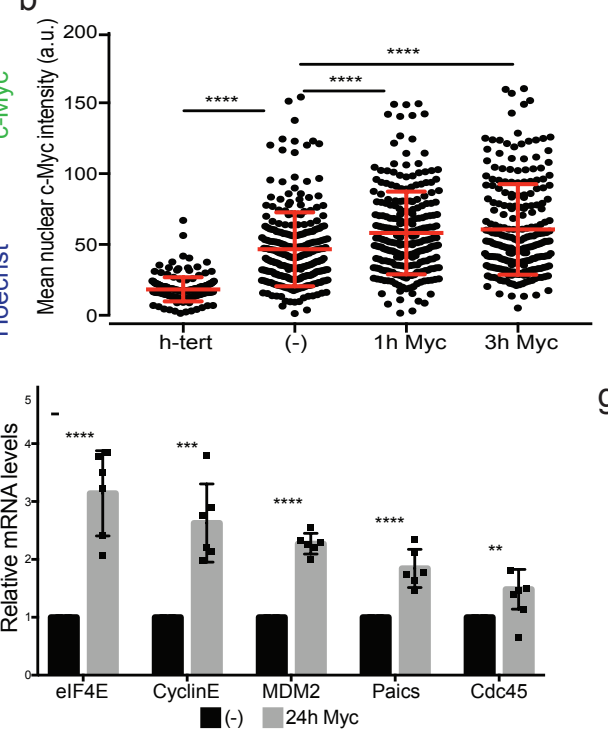

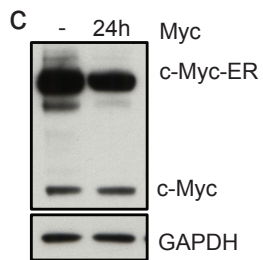

g

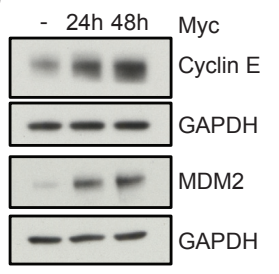

h RPE1 ER empty

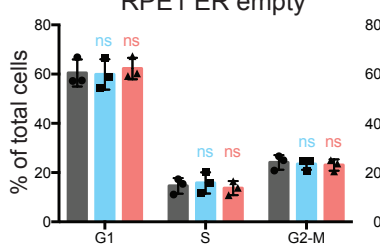

RPE1 c-Myc ER

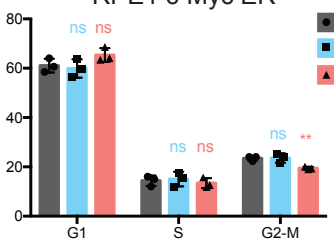

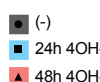

RPE1 ER RPE1 C-Myc

$48 \mathrm{~h} 4 \mathrm{OH}-\mathrm{T}$
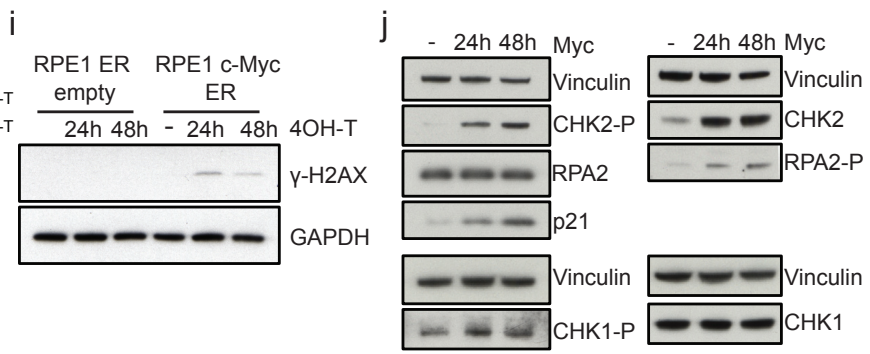

K RPE1 ER empty
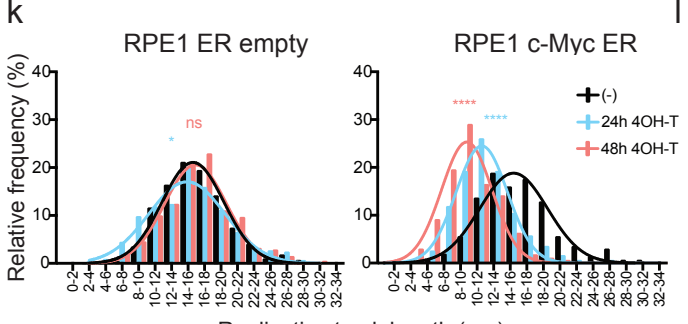

n

Replicative track length $(\mu \mathrm{m})$

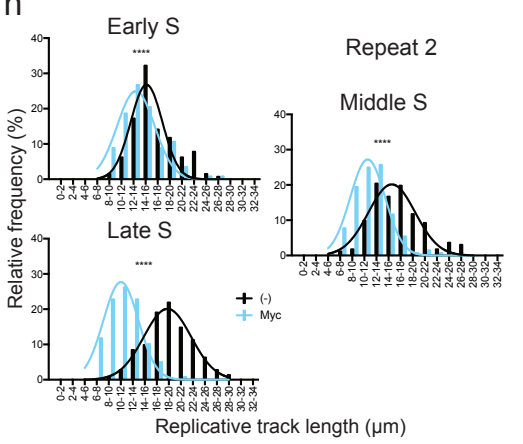

0

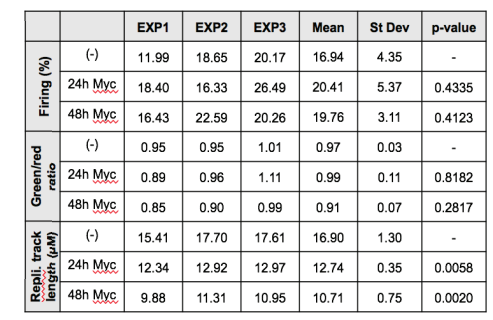

m

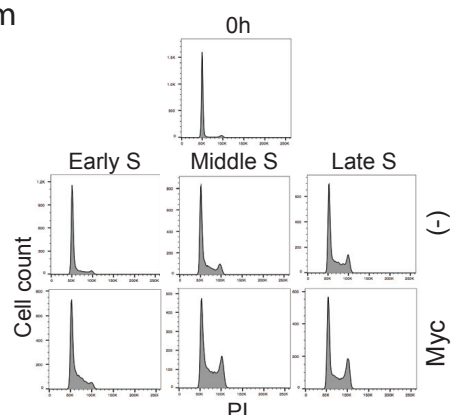

p

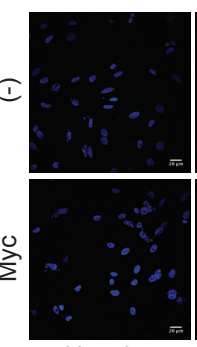

Hoechst

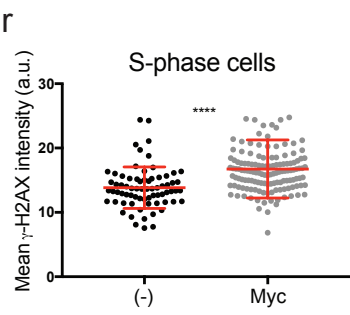

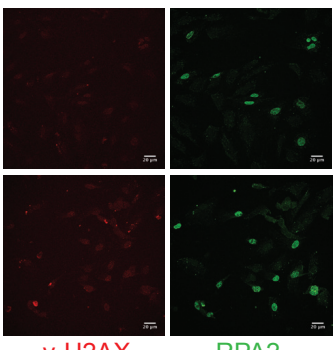

RPA2

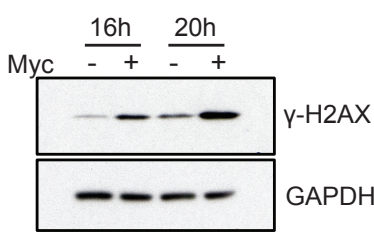

S-phase

Fig. S1. c-Myc-induced replication stress and DNA damage require G1 phase of the cell cycle. 
bioRxiv preprint doi: https://doi.org/10.1101/2021.07.25.453647; this version posted July 26, 2021. The copyright holder for this preprint (which was not certified by peer review) is the author/funder, who has granted bioRxiv a license to display the preprint in perpetuity. It is made available under aCC-BY 4.0 International license.

Fig. S1. a) Immunofluorescence staining of c-Myc in RPE1 h-TERT and RPE1 c-Myc-ER cells after addition of 4OH-T for the indicated times. b) Graph showing c-Myc mean intensity in individual RPE1 h-TERT and RPE1 c-Myc ER cell nuclei after addition of $4 \mathrm{OH}-\mathrm{T}$ for the indicated times, plotted in the scatter plot. p-value ${ }^{\star \star * *}<0.0001$ calculated with Mann-Whitney test. $\mathrm{n}=1$ experiment. c) Western blot of c-Myc in untreated cells and after $24 \mathrm{hr} 4 \mathrm{OH}-\mathrm{T}$ addition in RPE1 c-Myc ER cells. GAPDH is a loading control. Representative of $n=3$ experiments. d) Survival assay of untreated and c-Myc activated RPE1 c-Myc ER cells. Cells were treated with 48 hr with $4 \mathrm{OH}-\mathrm{T}$, plated in fresh media and colonies were left to grow for 7 days. Representative of $n=4$ experiments. e) Time course of the c-Myc target elF4E mRNA levels at the indicated time-points after $c-M y c$ activation. p-value ${ }^{* * *}=0.0009$ and $0.0006,{ }^{*}=0.02,0.01,0.01$ calculated with Student's t-test. $n=4$ experiments. f) mRNA levels of different c-Myc targets at 24 hr of $c-M y c$ activation. p-value ${ }^{* * * *}<0.0001,{ }^{* * *}=0.0002,{ }^{* *}=0.0062$ calculated with Student's t-test. $\mathrm{n}=4$ experiments. g) Western blot of the indicated c-Myc targets at 24 hr and $48 \mathrm{hr}$ of c-Myc activation. GAPDH is a loading control. Representative of $n=3$ experiments. h) Cell cycle distribution determined by PI staining and FACS analysis of c-Myc ER and RPE1 ER empty cells with and without $4 \mathrm{OH}-\mathrm{T}$ addition at the indicated time points. RPE1 c-Myc ER: $p$-value ${ }^{\star *}=0.0038$ calculated with Student's t-test. $n=3$ experiments. i) Western blot of $\gamma \mathrm{H} 2 \mathrm{AX}$ at the indicated time-points upon $4 \mathrm{OH}-\mathrm{T}$ addition in RPE1 c-Myc ER and RPE1 ER empty cell lines. GAPDH is a loading control. Representative of $n=3$ experiments. j) Western blot of the indicated proteins at $24 \mathrm{hr}$ and $48 \mathrm{hr}$ of $\mathrm{c}$-Myc activation. Vinculin is a loading control. Representative of $\mathrm{n}=3$ experiments. k) Histograms reporting the distribution of fibre length for control and c-Myc-induced cells at the indicated times of c-Myc activation in RPE1 c-Myc ER and RPE1 ER empty cell lines; RPE1 c-Myc ER: $p$-value ${ }^{\star \star * *}<0.0001$ calculated with Mann-Whitney test. RPE1 ER empty: $p$-value ${ }^{*}=0.01$ calculated with Mann-Whitney test. Pool of $n=3$ experiments. I) Table showing the percentage of origin firing, replication fork asymmetry (green/red ratio) and DNA fibre length for the experiments analysed in Figure S1k at $24 \mathrm{hr}$ and $48 \mathrm{hr}$ of c-Myc activation. Reported p-values were calculated with Student's t-test. $\mathrm{m}$ ) Cell cycle profile at the indicated time-points after release from G1 with and without c-Myc activation. Early: between $16 \mathrm{hr}$ and $18 \mathrm{hr}$; middle: between $20 \mathrm{hr}$ and $22 \mathrm{hr}$; late: $24 \mathrm{hr} . \mathrm{n}$ ) Repeat of Figure 1d. Histograms reporting the distribution of fibre length for control and c-Myc-induced cells at the reported times after release from arrest; early=18 hr, middle=22 hr, late=24 hr; p-value ${ }^{\star \star \star *}<0.0001 \mathrm{calculated}$ with Mann-Whitney test. Repeat 2 of $n=2$ experiments. o) Schematic of the synchronisation experiments for G1 release with nocodazole. RPE1 c-Myc ER cells were treated with nocodazole for 8 hr. After mitotic shake-off cells were plated in fresh media. After cells were released into G1, $4 \mathrm{OH}-\mathrm{T}$ was added to induce c-Myc or left untreated as control. $\mathrm{p}$ ) Representative images of RPA and $\gamma \mathrm{H} 2 \mathrm{AX}$ immunofluorescence. q) Immunofluorescence staining of chromatin-bound RPA and $\gamma \mathrm{H} 2 \mathrm{AX}$ after nocodazole arrest. Scatter plot showing the intensity of RPA and $\gamma \mathrm{H} 2 \mathrm{AX}$ signal in single nuclei. Black=RPA negative cells, orange=RPA positive cells, red=RPA positive cells with higher $\gamma \mathrm{H} 2 \mathrm{AX}$ signal. $\mathrm{n}=1$ experiment. $\mathrm{r}$ ) Graph showing $\gamma \mathrm{H} 2 \mathrm{AX}$ intensity in individual $\mathrm{S}$ phase cells plotted in the scatter plot. $\mathrm{p}$-value ${ }^{\star \star \star *}<0.0001$ calculated with Mann-Whitney test. $\mathrm{n}=1$ experiment. $\mathrm{s}$ ) Western blot of $\gamma \mathrm{H} 2 \mathrm{AX}$ at the indicated time-points after release from nocodazole arrest, with and without c-Myc activation. GAPDH is a loading control. Representative of $\mathrm{n}=2$ experiments. 
bioRxiv preprint doi: https://doi.org/10.1101/2021.07.25.453647; this version posted July 26, 2021. The copyright holder for this preprint (which was not certified by peer review) is the author/funder, who has granted bioRxiv a license to display the preprint in perpetuity. It is made available under aCC-BY 4.0 International license.

a
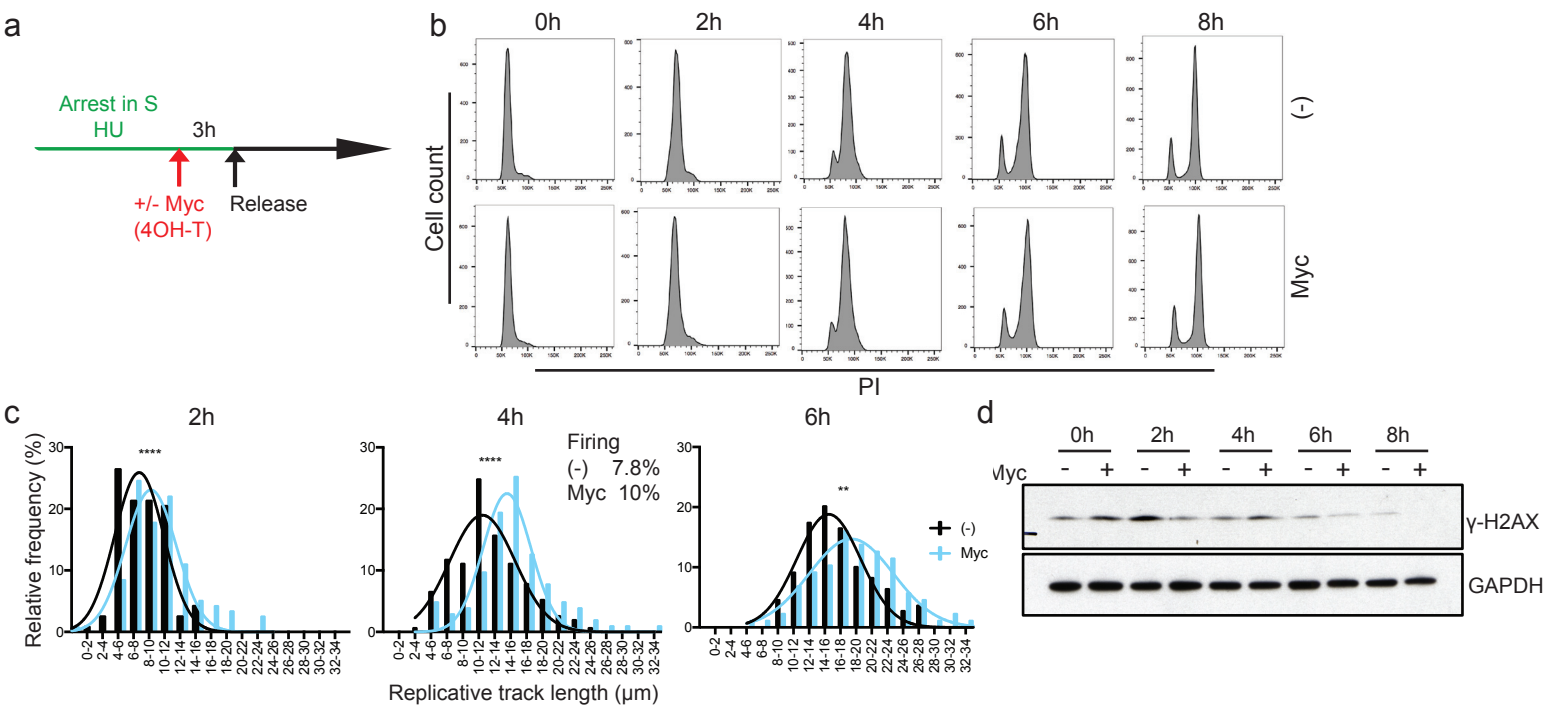

e

f

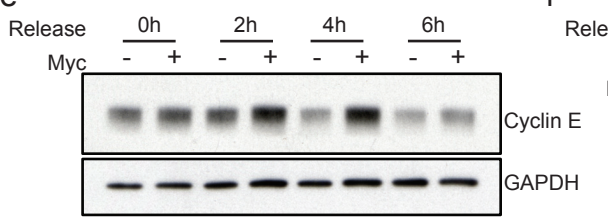

$\mathrm{h}$

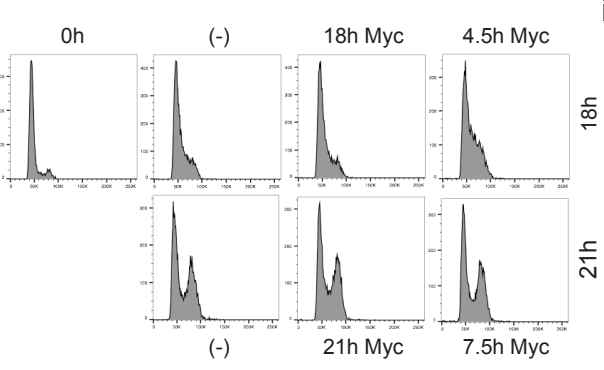

i Release $18 \mathrm{~h} \quad 21 \mathrm{~h}$ g

Myc $-18 \mathrm{~h} 4.5 \mathrm{~h}-21 \mathrm{~h} 7.5 \mathrm{~h}$

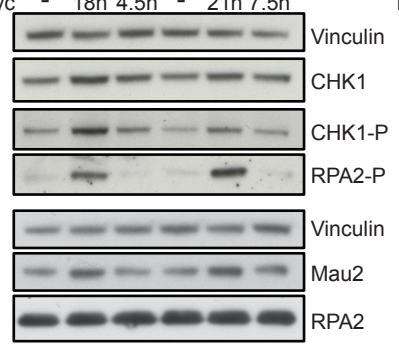

j

$\mathrm{k}$

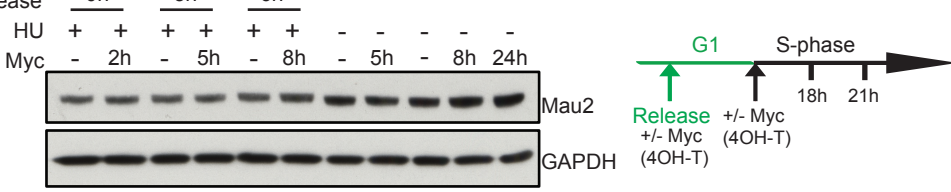

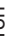

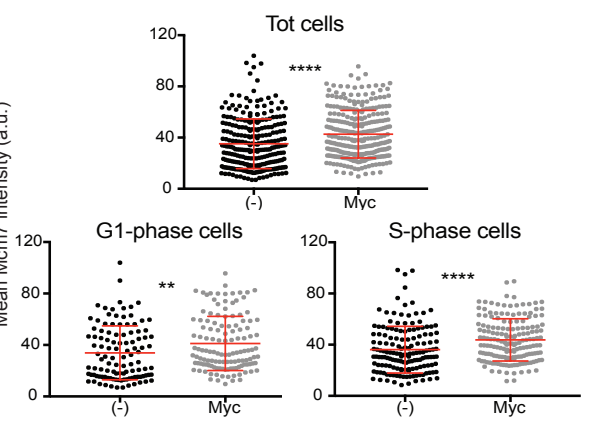

I

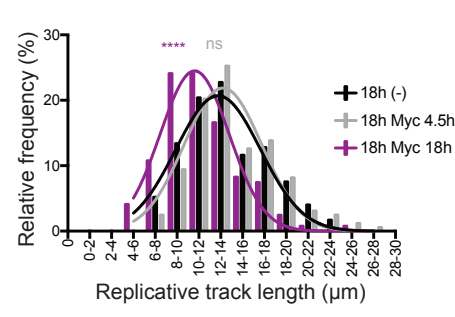

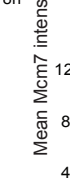

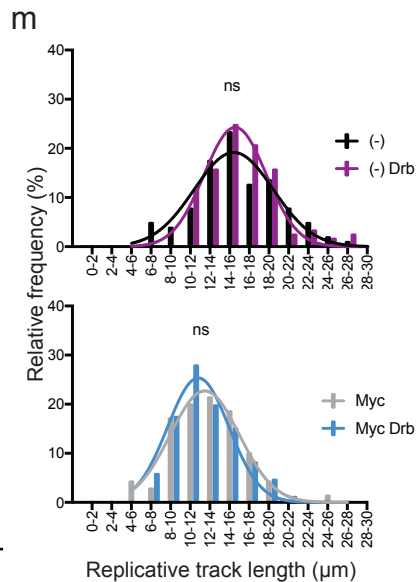

Fig. S2. Replication initiation and replication-transcription collisions are not involved in generating replication stress and DNA damage upon c-Myc activation. 
bioRxiv preprint doi: https://doi.org/10.1101/2021.07.25.453647; this version posted July 26, 2021. The copyright holder for this preprint (which was not certified by peer review) is the author/funder, who has granted bioRxiv a license to display the preprint in perpetuity. It is made available under aCC-BY 4.0 International license.

Fig. S2. a) Schematic of the synchronisation experiments for S release with HU. RPE1 c-Myc ER cells were arrested in HU overnight. 4-OHT was added 3 hr before release. Cells were then washed and released in S. b) Cell cycle profile at the indicated time-points after release from S with and without c-Myc activation. c) Histograms reporting the distribution of fibre length for control and c-Myc-induced cells at the reported times after release from $\mathrm{HU}$ arrest; $\mathrm{p}$-value ${ }^{* * * *}<0.0001,{ }^{* *}=0.006$ calculated with Mann-Whitney test. $\mathrm{n}=1$ experiment. d) Western blot of $\gamma \mathrm{H} 2 \mathrm{AX}$ at the indicated time-points after release from HU-arrest, with and without c-Myc activation. GAPDH is a loading control. Representative of $n=3$ experiments. e) Western blot of Cyclin E at the indicated time-points after release from HU-arrest, with and without c-Myc activation. GAPDH is a loading control. Representative of $n=3$ experiments. f) Western blot of Mau2 at the indicated time-points after release from HU-arrest and in asynchrounous cells, with and without c-Myc activation for the indicated time-points. GAPDH is a loading control. Representative of $n=3$ experiments. g) Schematic of the synchronisation experiments for G1 release with Palbociclib. RPE1 c-Myc ER cells were arrested in G1 for $24 \mathrm{hr}$. Cells were then released and $4 \mathrm{OH}-\mathrm{T}$ was added immediately upon release or $14 \mathrm{hr}$ later, when cells enter S-phase. Cells were then collected at $18 \mathrm{hr}$ and $21 \mathrm{hr}$ after release. h) Cell cycle profile at the indicated time-points after release from Palbociclib G1-arrest with and without c-Myc activation for the indicated times. i) Western blot of the indicated proteins after release from Palbociclib G1-arrest, with and without c-Myc activation for the indicated times. GAPDH and Vinculin are loading controls. Representative of $n=3$ experiments. j) Histograms reporting the distribution of fibre length for control and c-Myc-induced cells at the reported times after release from Palbociclib G1-arrest; $p$-value ${ }^{\star * * *}<0.0001$ calculated with Mann-Whitney test. $n=1$ experiment. $k$ ) Graph showing chromatin-bound Mcm7 intensity in individual total, G1 and S phase pre-extracted nuclei after $18 \mathrm{hr}$ from release from G1, plotted in the scatter plot. $\mathrm{p}$-value ${ }^{\star \star \star \star}<0.0001$ calculated with the Mann-Whitney test. $\mathrm{n}=1$ experiment. I) Left: representative images of EU levels in control and c-Myc-induced cells with and without the addition of DRB for $2 \mathrm{hr}$. Right: graph showing EU intensity in individual cell nuclei plotted in the scatter plot at $20 \mathrm{hr}$ after release from G1-arrest with and without the addition of DRB for $2 \mathrm{hr}$ and c-Myc activation; $p$-value ${ }^{\star * \star *}<0.0001$ calculated with Mann-Whitney test. Representative of $n=3$ experiments. $m$ ) Histograms reporting the distribution of fibre length for control and c-Myc-induced cells at $20 \mathrm{hr}$ after release from G1-arrest with and without the addition of DRB for $2 \mathrm{hr}$; $\mathrm{p}$-value calculated with Mann-Whitney test. Representative of $n=3$ experiments. 
bioRxiv preprint doi: https://doi.org/10.1101/2021.07.25.453647; this version posted July 26, 2021. The copyright holder for this preprint (which was not certified by peer review) is the author/funder, who has granted bioRxiv a license to display the preprint in perpetuity. It is made available under aCC-BY 4.0 International license.

a

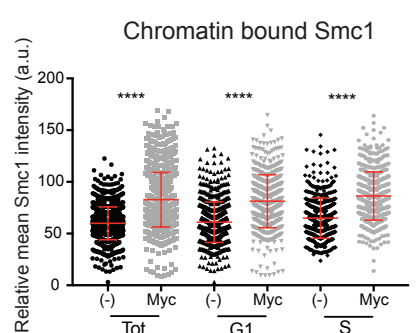

c
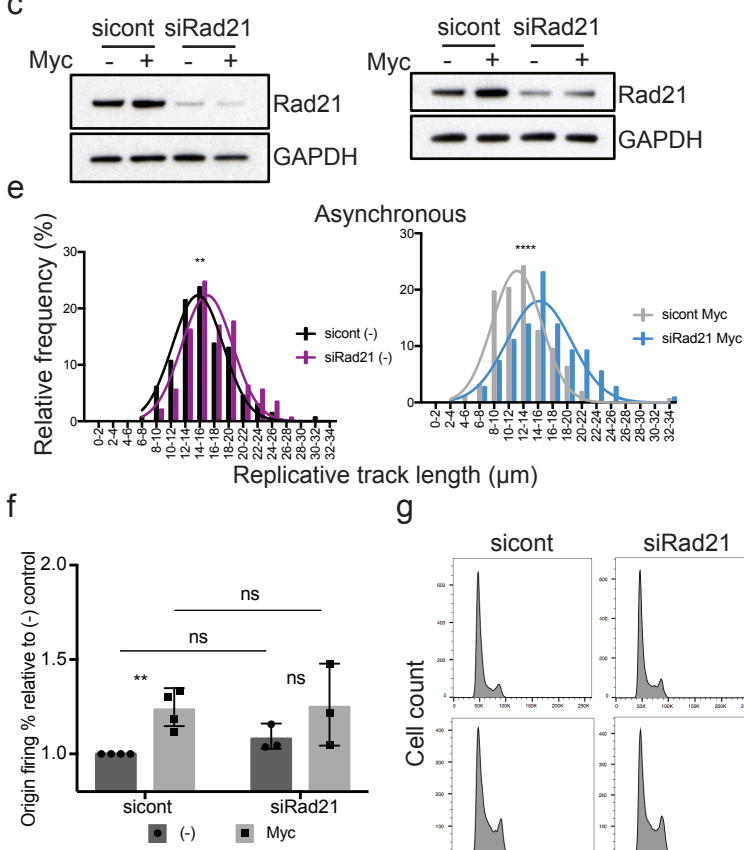

g

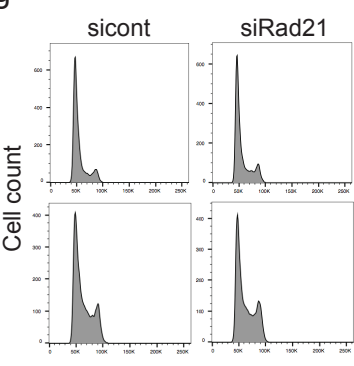

$\mathrm{P}$

j
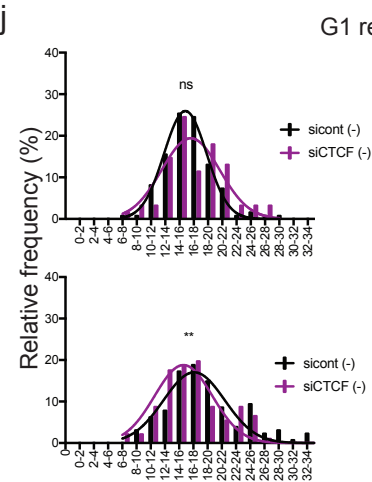

$\mathrm{m}$

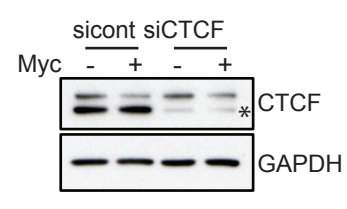

I

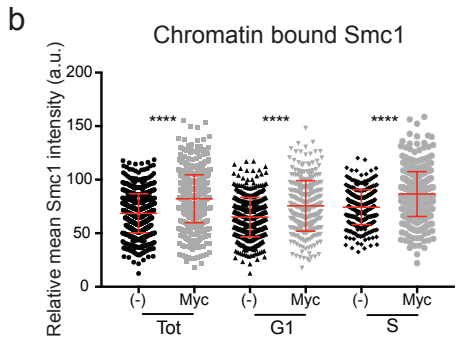

d

G1 release

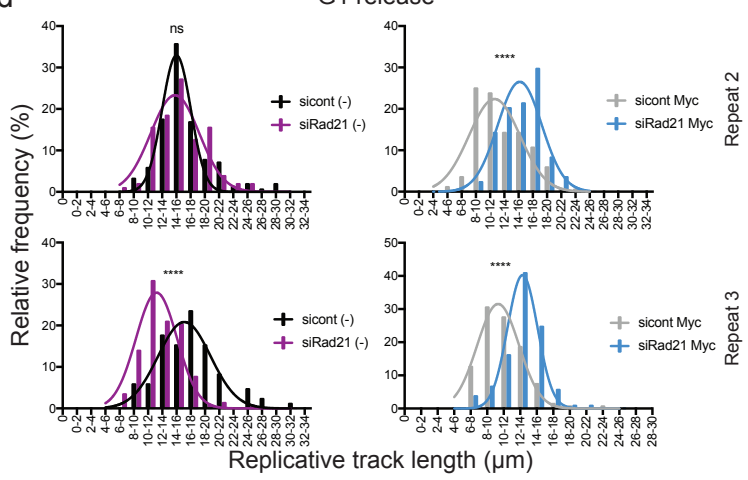

$\mathrm{h}$

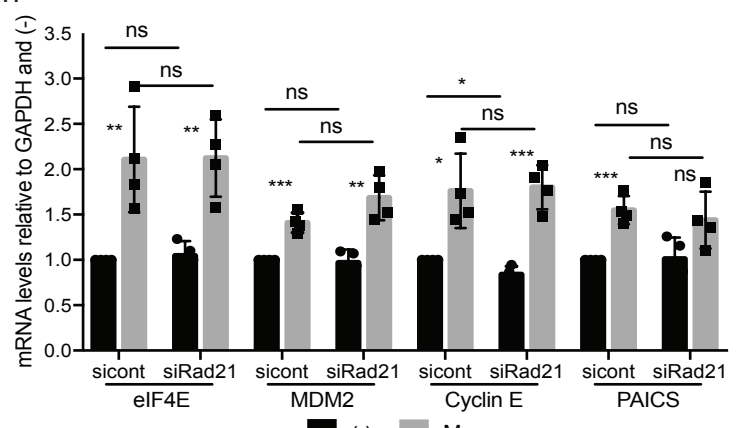

廿(-) Myc
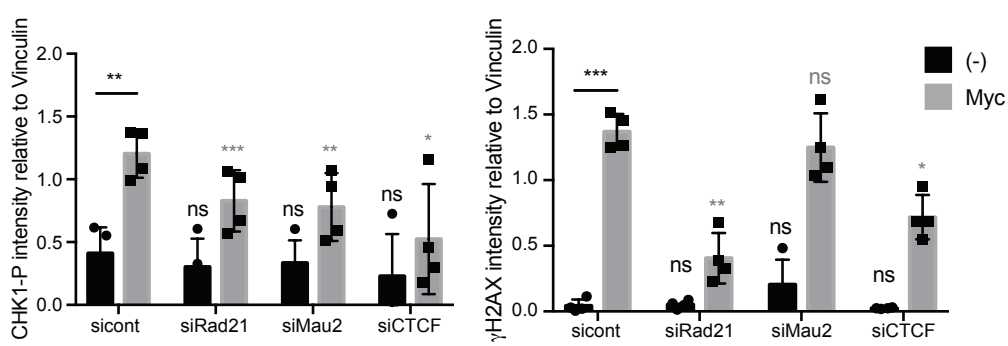

Fig. S3. Reducing the levels of cohesin on chromatin or at CTCF sites prevents c-Myc induced replication stress without affecting the extent of origin firing and the cell cycle profiles. 
bioRxiv preprint doi: https://doi.org/10.1101/2021.07.25.453647; this version posted July 26, 2021. The copyright holder for this preprint (which was not certified by peer review) is the author/funder, who has granted bioRxiv a license to display the preprint in perpetuity. It is made available under aCC-BY 4.0 International license.

Fig. S3. a) Synchronised cells were released into the cell cycle and immunofluorescence of chromatin-bound cohesin subunits Smc1 and Smc3 were performed at $14 \mathrm{hr}$ after release. Graphs reporting the intensity of Smc1 and Smc3 chromatin signals in total, S phase and G1 phase single nuclei of untreated and c-Myc cells. p-value ****<0.0001 calculated with Mann-Whitney test. Pool of $n=3$ experiments. b) Graphs reporting the intensity of Smc1 chromatin signals in total, $S$ phase and G1 phase single nuclei in asynchronous population at $16 \mathrm{hr}$ of $\mathrm{c}-\mathrm{Myc}$ activation and in untreated cells; $\mathrm{p}$-value ${ }^{* * * *}<0.0001$ calculated with Mann-Whitney test. Pool of $\mathrm{n}=3$ experiments. c) Western blot showing Rad21 knock down in synchronous (left) and asynchronous (right) cells. GAPDH is a loading control. d) Histograms reporting the distribution of fibre length in synchronised sicontrol and siRad21 depleted cells. p-value ${ }^{* * * *}<0.0001$ calculated with Mann-Whitney test. Repeats 2 and 3 , Repeat 1 is in Figure 3 d. e) Histograms reporting the distribution of fibre length in asynchronous sicontrol and siRad21 depleted cells. p-value ${ }^{\star \star * *}<0.0001,{ }^{* *}=0.0026$ calculated with Mann-Whitney test. Representative of $\mathrm{n}=3$ experiments. f) Percentages of origin firing at $20 \mathrm{hr}$ after release from G1-arrest and Rad21 or sicontrol knock down, with and without c-Myc activation. $\mathrm{p}$-value ${ }^{\star \star}=0.0035$ calculated with Student's t-test. $n=3$ experiments. g) Cell cycle profile at $20 \mathrm{hr}$ after release from G1 and Rad21 or sicontrol knock down, with and without c-Myc activation. Representative of $n=3$ experiments. h) mRNA levels of different c-Myc targets in control and Rad21 depleted cells at 24 hr of c-Myc activation. $\mathrm{p}$-value calculated with Student's t-test. $n=4$ experiments. i) Western blot showing CTCF knock down in synchronous cells. GAPDH is a loading control. j) Histograms reporting the distribution of fibre length in synchronised sicontrol and siCTCF depleted cells. p-value ${ }^{\star * * *}<0.0001,{ }^{* *}=0.0078$ calculated with Mann-Whitney test. Repeats 2 and 3 , repeat 1 is in Figure 3 h. k) Cell cycle profile at $20 \mathrm{hr}$ after release from G1 and CTCF or sicontrol knock down, with and without c-Myc activation. Representative of $n=3$ experiments. I) Western blot of the indicated proteins in control, Rad21, CTCF and Mau2 depleted cells upon $24 \mathrm{hr}$ of c-Myc activation. Vinculin is a loading control. Representative of $\mathrm{n}=4$ experiments. m) Western blot quantification of the indicated proteins in control, Rad21, CTCF and Mau2 depleted cells upon $24 \mathrm{hr}$ of c-Myc activation relative to Vinculin. $\mathrm{n}=4$ experiments. 
bioRxiv preprint doi: https://doi.org/10.1101/2021.07.25.453647; this version posted July 26, 2021. The copyright holder for this preprint (which was not certified by peer review) is the author/funder, who has granted bioRxiv a license to display the preprint in perpetuity. It is made available under aCC-BY 4.0 International license.

a

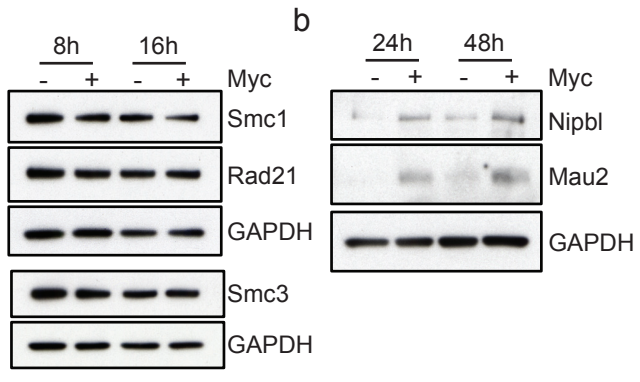

e

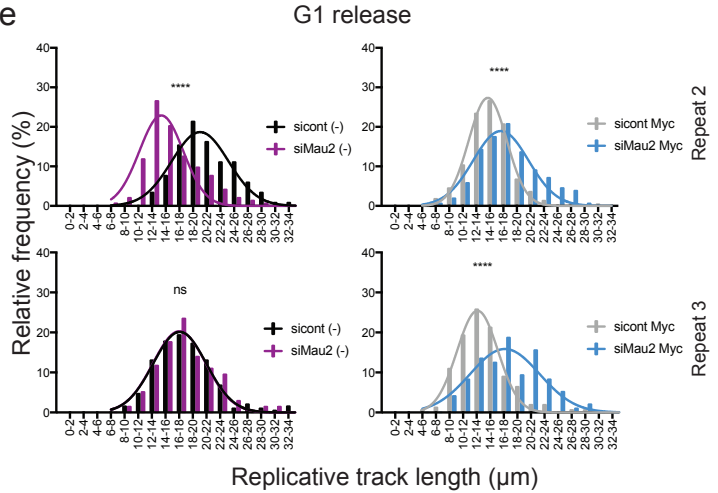

C

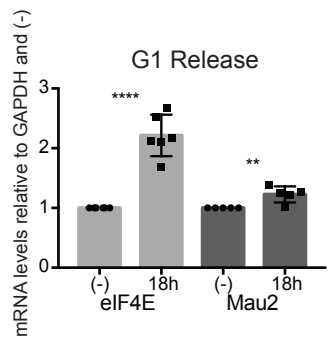

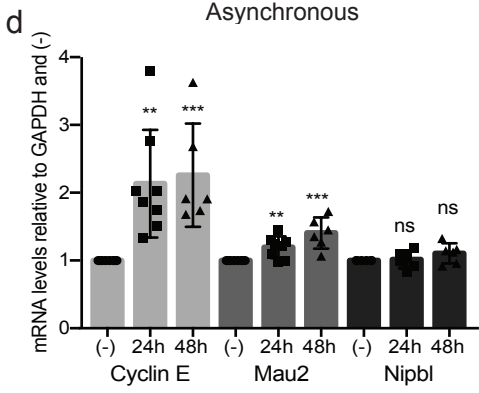
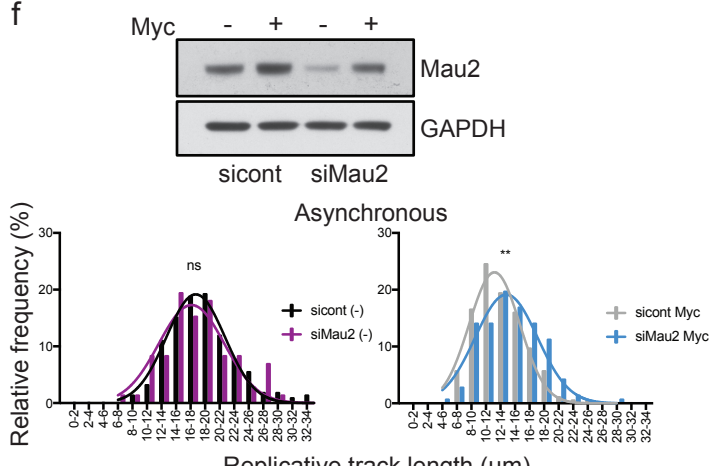

Replicative track length $(\mu \mathrm{m})$

g

h Mau2-
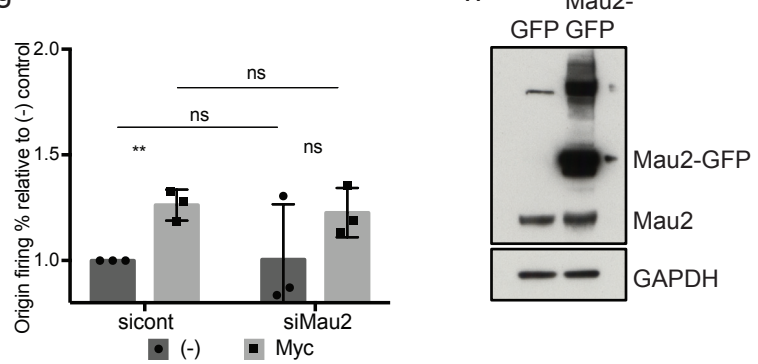

i Mau2-
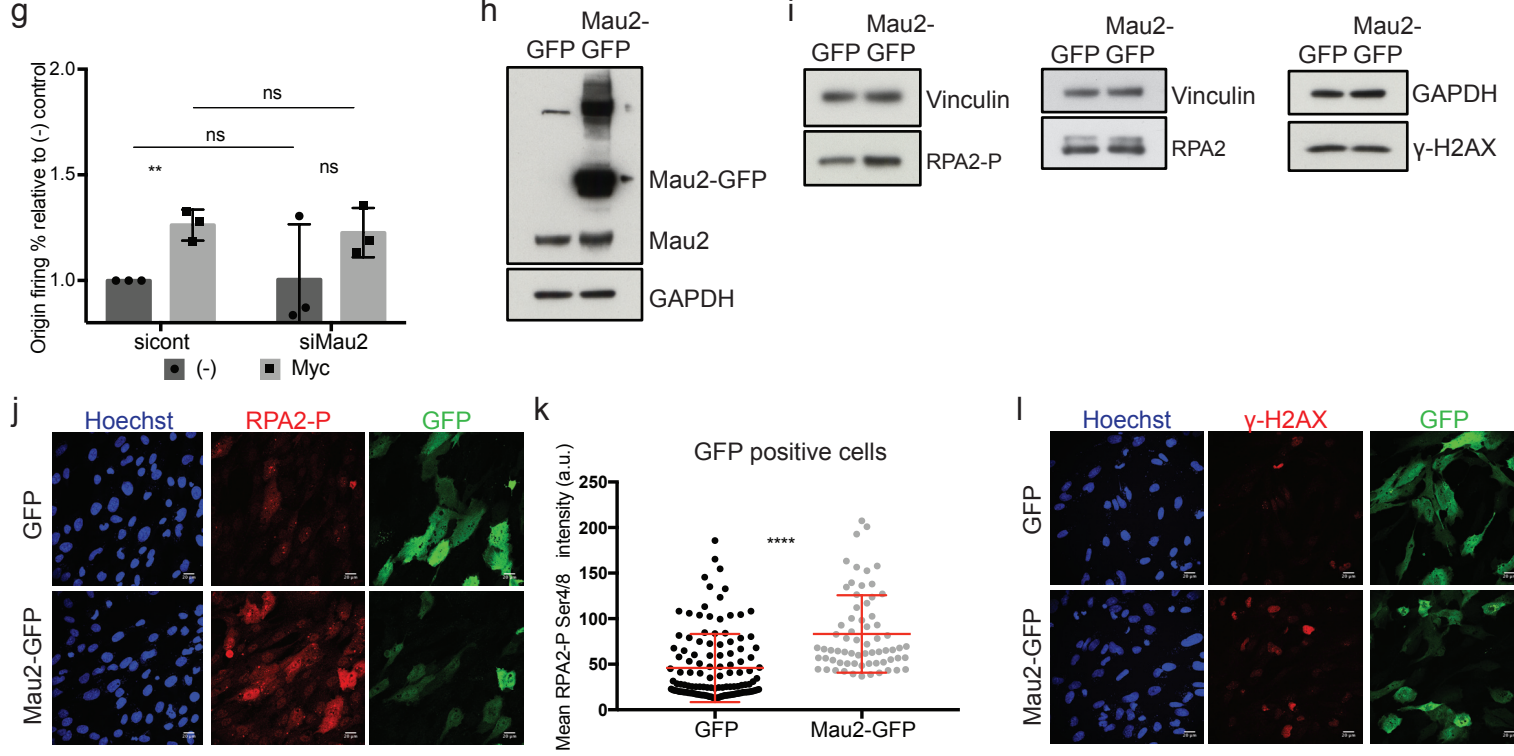

GFP positive cells

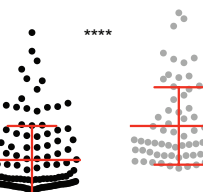

GFP
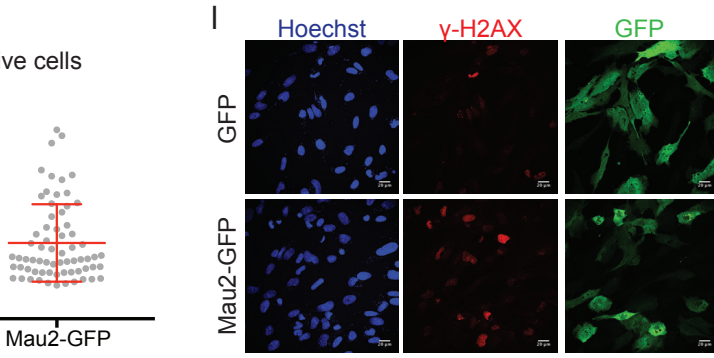

$\mathrm{m}$

n

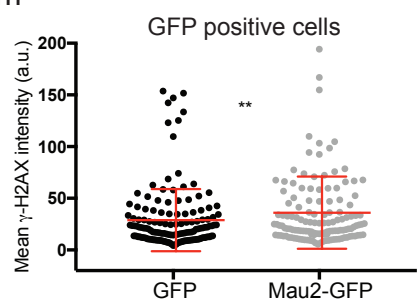

O
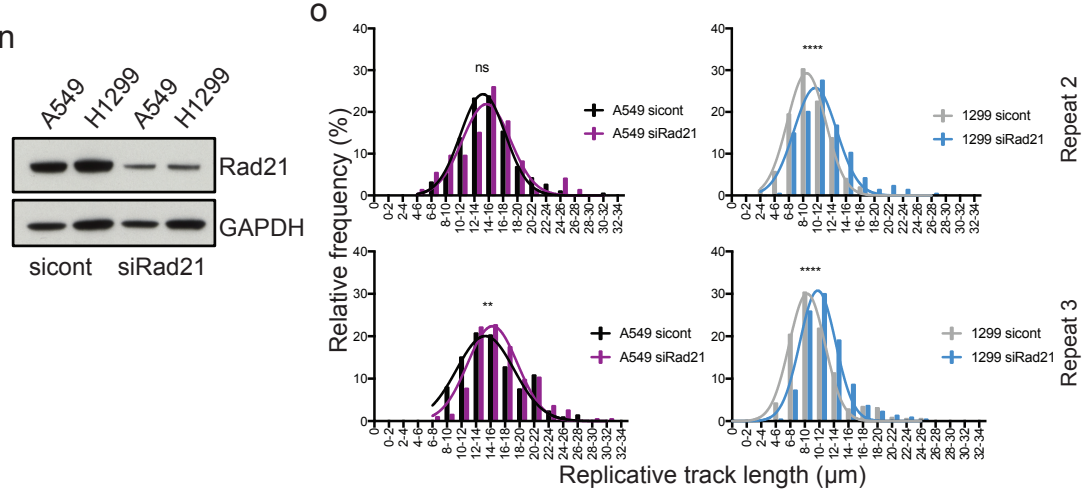

Fig. S4. Dysregulation of the cohesin loader Mau2 is required for C-Myc-induced replication stress. 
bioRxiv preprint doi: https://doi.org/10.1101/2021.07.25.453647; this version posted July 26, 2021. The copyright holder for this preprint (which was not certified by peer review) is the author/funder, who has granted bioRxiv a license to display the preprint in perpetuity. It is made available under aCC-BY 4.0 International license.

Fig. S4. a) Western blot showing total levels of cohesin subunits and regulators in asynchronous population with and without c-Myc activation for the indicated time-points. Representative experiment of $n=2$. b) Western blot showing total levels of the cohesin loaders Mau2 and Nipbl in asynchronous cells at 24 hr and 48 hr of $c-M y c$ activation. Representative experiment of $n=3$. c) mRNA levels of Mau2 at $18 \mathrm{hr}$ of c-Myc activation in synchronised cells. $p$-value ${ }^{\star * * *}<0.0001$, ${ }^{* *}=0.0056$ calculated with Student's t-test. $\mathrm{n}=6$ experiments. d) $\mathrm{mRNA}$ levels of Mau2 and NIPBL at the indicated time-points of $\mathrm{c}-\mathrm{Myc}$ activation in asynchronous population. $\mathrm{p}$-value ${ }^{\star \star *}=0.0005,0.0003,{ }^{* *}=$ $0.0012,0.0042$ calculated with Student's t-test. $n=6$ experiments. e) Histograms reporting the distribution of fibre length in synchronised sicontrol and siMau2 depleted cells. p-value ${ }^{* * *}<0.0001$ calculated with Mann-Whitney test. Repeats 2 and 3, repeat 1 is in 4g. f) Top: Western blot showing Mau2 knock-down in asynchronous population. GAPDH is a loading control. Bottom: histograms reporting the distribution of fibre length in asynchronous sicontrol and siMau2 depleted cells. $p$-value ${ }^{\star *}=0.0057$ calculated with Mann-Whitney test. $\mathrm{n}=1$ experiment. g) Percentages of origin firing at $20 \mathrm{hr}$ after release from G1-arrest and Mau2 knock-down, with and without c-Myc activation. $p$-value ${ }^{* *}=0.0034$ calculated with Student's t-test. $n=3$ experiments. $h$ ) Western blot showing total levels of Mau2 in RPE1 h-TERT cells after transient transfection with GFP and Mau2-GFP plasmids for $24 \mathrm{hr}$. Representative of $n=4$ experiments. i) Western blot showing total levels of the indicated proteins in RPE1 h-TERT cells after transient transfection with GFP and Mau2-GFP plasmids for $24 \mathrm{hr}$. Vinculin and GAPDH are loading controls. Representative of $n=4$ experiments. j) Representative images of GFP and RPA2 phospho S4/8 levels after transient transfection with GFP and Mau2-GFP plasmids for $24 \mathrm{hr}$. k) Graph showing RPA2 phospho S4/8 intensity in individual cell nuclei after transient transfection with GFP and Mau2-GFP plasmids for $24 \mathrm{hr}$ plotted in the scatter plot. Only GFP positive cells are shown. p-value ${ }^{\star \star \star *}<0.0001 \mathrm{calculated}$ with Mann-Whitney test. Representative of $n=3$ experiments. I) Representative images of GFP and $\gamma \mathrm{H} 2 A X$ levels after transient transfection with GFP and Mau2-GFP plasmids for $24 \mathrm{hr} . \mathrm{m}) \mathrm{Graph}$ showing $\gamma \mathrm{H} 2 \mathrm{AX}$ intensity in individual cell nuclei after transient transfection with GFP and Mau2-GFP plasmids for 24 hr plotted in the scatter plot. Only GFP positive cells are shown. $p$-value ${ }^{* *}=0.0074$ calculated with Mann-Whitney test. Representative of $n=3$ experiments. $n$ ) Western blot showing Rad21 knock down in A549 and $\mathrm{H} 1299$ cells. GAPDH is a loading control. o) Histograms reporting the distribution of fibre length in sicontrol and siRad21 depleted A549 and $\mathrm{H} 1299$ cells. p-value ${ }^{\star \star * *}<0.0001$, ${ }^{* *}=0.0031$ calculated with Mann-Whitney test. Repeats 2 and 3, repeat 1 is in $4 \mathrm{k}$. 